\title{
Carbon isotopes in the ocean model of the Community Earth System Model (CESM1)
}

\author{
A. Jahn ${ }^{1, a}$, K. Lindsay ${ }^{1}$, X. Giraud ${ }^{2,3}$, N. Gruber ${ }^{3}$, B. L. Otto-Bliesner ${ }^{1}$, Z. Liu ${ }^{4}$, and E. C. Brady ${ }^{1}$ \\ ${ }^{1}$ National Center for Atmospheric Research, Climate and Global Dynamics Division, Boulder, CO, USA \\ ${ }^{2}$ Aix Marseille Université, CNRS, IRD, Collège de France, CEREGE UM34, Aix en Provence, France \\ ${ }^{3}$ Environmental Physics Group, Institute of Biogeochemistry and Pollutant Dynamics, ETH Zürich, Zürich, Switzerland \\ ${ }^{4}$ Department of Atmospheric and Oceanic Sciences, and Center for Climatic Research, University of Wisconsin - Madison, \\ Madison, WI, USA \\ anow at: the Department of Atmospheric and Oceanic Sciences and the Institute of Arctic and Alpine Research at the \\ University of Colorado Boulder, Boulder, CO, USA
}

Correspondence to: A. Jahn (alexandra.jahn@ colorado.edu)

Received: 20 September 2014 - Published in Geosci. Model Dev. Discuss.: 6 November 2014

Revised: 13 July 2015 - Accepted: 14 July 2015 - Published: 5 August 2015

\begin{abstract}
Carbon isotopes in the ocean are frequently used as paleoclimate proxies and as present-day geochemical ocean tracers. In order to allow a more direct comparison of climate model results with this large and currently underutilized data set, we added a carbon isotope module to the ocean model of the Community Earth System Model (CESM), containing the cycling of the stable isotope ${ }^{13} \mathrm{C}$ and the radioactive isotope ${ }^{14} \mathrm{C}$. We implemented the ${ }^{14} \mathrm{C}$ tracer in two ways: in the "abiotic" case, the ${ }^{14} \mathrm{C}$ tracer is only subject to airsea gas exchange, physical transport, and radioactive decay, while in the "biotic" version, the ${ }^{14} \mathrm{C}$ additionally follows the ${ }^{13} \mathrm{C}$ tracer through all biogeochemical and ecological processes. Thus, the abiotic ${ }^{14} \mathrm{C}$ tracer can be run without the ecosystem module, requiring significantly fewer computational resources. The carbon isotope module calculates the carbon isotopic fractionation during gas exchange, photosynthesis, and calcium carbonate formation, while any subsequent biological process such as remineralization as well as any external inputs are assumed to occur without fractionation. Given the uncertainty associated with the biological fractionation during photosynthesis, we implemented and tested three parameterizations of different complexity. Compared to present-day observations, the model is able to simulate the oceanic ${ }^{14} \mathrm{C}$ bomb uptake and the ${ }^{13} \mathrm{C}$ Suess effect reasonably well compared to observations and other model
\end{abstract}

studies. At the same time, the carbon isotopes reveal biases in the physical model, for example, too sluggish ventilation of the deep Pacific Ocean.

\section{Introduction}

A large fraction of paleoclimatic reconstructions are based on isotopic measurements (e.g., Petit et al., 1999; McDermott, 2004; Curry and Oppo, 2005; Polka et al., 2013), yet there are many uncertainties associated with the interpretation of these records in terms of physical climate variables such as temperature, precipitation, and ocean circulation rates. More direct comparisons of paleo data with climate models would therefore be beneficial, both to test the interpretation of the isotopic proxy data and to allow for better comparisons of model simulations with proxy data. Furthermore, many isotope tracers are currently being measured in the ocean, and including them in ocean models can help us better understand the ocean circulation and diagnose model biases (e.g., Matsumoto et al., 2004). For all of these reasons, we have added a carbon isotope module to the ocean model of the Community Earth System Model (CESM) (Hurrell et al., 2013).

Carbon has two stable isotopes, ${ }^{12} \mathrm{C}$ and ${ }^{13} \mathrm{C}$. More than $98.9 \%$ of carbon on earth is ${ }^{12} \mathrm{C}$, while ${ }^{13} \mathrm{C}$ makes up most 
of the remaining $1 \%$. The radioactive carbon isotope ${ }^{14} \mathrm{C}$, also called radiocarbon, is present only in trace amounts (approximately $1 \times 10^{-10} \%$ of all carbon) and has a half-life of 5730 years (Godwin, 1962). Radiocarbon is a useful tracer to evaluate the ventilation of the deep ocean because it acts as a clock, measuring the time since water was last in contact with the atmosphere (e.g., Toggweiler et al., 1989; Orr, 2002; Meissner et al., 2003; Waugh et al., 2003; Key et al., 2004; Doney et al., 2004; Matsumoto et al., 2004; Meissner, 2007; Bardin et al., 2014). Because of the atmospheric nuclear weapons tests in the 1950s and 1960s and the wellknown input function of radiocarbon during this time, radiocarbon is also useful to evaluate the recent penetration of anthropogenic carbon into the ocean (e.g., Graven et al., 2012). Furthermore, oceanic radiocarbon has been used to determine the mean gas exchange velocity used in ocean models (e.g., Wanninkhof, 1992; Sweeney et al., 2007; Naegler et al., 2006; Naegler, 2009). Oceanic $\delta^{13} \mathrm{C}$ has been used in paleoclimate studies as a tracer of the ocean circulation (e.g., Marchal et al., 1998; Curry and Oppo, 2005; Crucifix, 2005), to calculate the uptake of anthropogenic carbon dioxide (e.g., Keeling et al., 1980; Quay et al., 1992; Gruber et al., 1999; Sonnerup et al., 1999; Gruber and Keeling, 2001), and to diagnose biases in marine ecosystem models (e.g., Schmittner et al., 2013).

We added the carbon isotopes to the code so that they follow the cycling of total carbon through all ecosystem and physical/chemical processes. In this biotic formulation, a new ${ }^{13} \mathrm{C}$ and ${ }^{14} \mathrm{C}$ state variable was added to each carbonbearing state variable, resulting in a total of 14 new state variables. For ${ }^{14} \mathrm{C}$, we also added the option of a simplified representation, where the isotope is only subject to the main chemical and physical processes during gas exchange and decay, but does not cycle through the ecosystem. This abiotic formulation of ${ }^{14} \mathrm{C}$ was implemented based on the Ocean Carbon Model Intercomparison Project Phase 2 (OCMIP-2) protocol (Orr et al., 2000).

Abiotic radiocarbon had been added previously to the NCAR ocean model (in NCOM1.4, Orr, 2002, and POP1/CCSM3, Graven et al., 2012), and biotic ${ }^{13} \mathrm{C}$ was implemented in the ecosystem model of the CCSM3 by X. Giraud and N. Gruber in 2009-2010. However, neither development was ever added to the trunk of the ocean model code of the CESM, so it was not maintained as the model evolved over the years and consequently none of these implementations still work in the current ocean model of the CESM. In contrast, the addition of a biotic radiocarbon tracer is completely new in this implementation in the CESM. In order to increase the chances of maintaining these developments as the model continues to evolve, the current implementation has been added to the code trunk of the current ocean model of CESM. By including carbon isotopes in the ocean model of the CESM1, the CESM1 joins the community of other comprehensive ocean general circulation models that include abiotic radiocarbon and/or biotic ${ }^{13} \mathrm{C}$ in the ocean (e.g., Mo-
BidiC, Crucifix, 2005; PISCES, Tagliabue and Bopp, 2008; CM2Mc ESM, Galbraith et al., 2011; HAMOCC2s, Hesse et al., 2011; and UVic ESCM, e.g., Meissner et al., 2003; Schmittner et al., 2013). While the abiotic radiocarbon implementation tends to follow the OCMIP-2 protocol (Orr et al., 2000) in all models, the implementations of biotic ${ }^{13} \mathrm{C}$ differ between models, mainly due to the complexity of the ocean biogeochemistry model used in them, but also due to different choices in regards to the parameterization of the biological fractionation during photosynthesis and calcium carbonate $\left(\mathrm{CaCO}_{3}\right)$ formation.

As a reference for future studies using these new capabilities in the CESM, we describe the model used (Sect. 2), describe the details of the implementation of the abiotic and biotic carbon isotopes (Sect. 3), and compare the simulated carbon-isotope fields to observational data to show the general performance of the model (Sect. 4).

\section{Model}

This work was done using the code base of the Community Earth System Model (CESM) (Hurrell et al., 2013), version 1.0.5. The isotope code has been updated to the current version of the CESM and is targeted for public release in 2016 as part of CESM2 (see the section on code availability at the end of the article). The CESM is a fully coupled climate model with components for the atmosphere, land, river runoff, sea ice, ocean and ice sheets, coupled by a coupler. Its components and simulations have been described in a large collection of articles, many of them contained in a special collection in the Journal of Climate (http://journals.ametsoc.org/ page/CCSM4/CESM1). The simulations analyzed here were performed using the ocean model coupled to data models for the atmosphere, the land, the sea ice, and the river routing, using repeated normal year forcing from CORE-II (Large and Yeager, 2009). The ocean model was run at a nominal $3^{\circ}$ horizontal resolution with 60 vertical levels, which is the lowresolution configuration of the ocean model (Shields et al., 2012). This ocean-only model version with ocean biogeochemistry at $3^{\circ}$ model resolution is used as a low-cost test bed for model development, but is not scientifically validated or supported. Hence, future science applications of the carbon isotopes should use the scientifically supported $1^{\circ}$ horizontal resolution model version of the CESM.

\section{Carbon isotope implementation}

The carbon isotopes were added as optional passive tracers, with the biotic and abiotic implementations as two different options that can be set at the compilation and build time. The abiotic ${ }^{14} \mathrm{C}$ can be run with or without the ocean ecosystem model, while the biotic ${ }^{13} \mathrm{C}$ and ${ }^{14} \mathrm{C}$ require the ocean ecosystem model to be turned on. 


\subsection{Abiotic ${ }^{14} \mathrm{C}$}

In this implementation, $\mathrm{DI}^{14} \mathrm{C}$ is the model's normalized concentration of total dissolved inorganic ${ }^{14} \mathrm{C}$, following the OCMIP2 protocol (Orr et al., 2000). DI ${ }^{14} \mathrm{C}$ is used as normalized concentration in order to minimize the numerical error of carrying very small numbers. The normalization is done by dividing the real $\mathrm{DI}^{14} \mathrm{C}$ by the standard ratio of ${ }^{14} \mathrm{C} /{ }^{12} \mathrm{C}=1.176 \times 10^{-12}$ (Karlen et al., 1968). To obtain comparable $\mathrm{DI}^{14} \mathrm{C}$ values as measured, we multiply the simulated $\mathrm{DI}^{14} \mathrm{C}$ by this scaling factor of $1.176 \times 10^{-12}$. Since the abiotic radiocarbon is designed to be run without the ocean ecosystem active, we also carry an abiotic $\mathrm{DI}^{12} \mathrm{C}$ tracer to calculate the isotope ratio ${ }^{14} R=\mathrm{DI}^{14} \mathrm{C} / \mathrm{DI}^{12} \mathrm{C}$. For comparisons with observations, we calculate $\Delta^{14} \mathrm{C}$ as a diagnostic variable:

$\Delta{ }^{14} \mathrm{C}=\left({ }^{14} R-1\right) \cdot 1000$.

By construction, the abiotic $\mathrm{DI}^{12} \mathrm{C}$ and $\mathrm{DI}^{14} \mathrm{C}$ tracers only depend on the solubility of carbon in seawater and neglect all biological activity. The error in $\Delta^{14} \mathrm{C}$ due to neglecting biology activity has been estimated to be on the order of $10 \%$ (Fiadiero, 1982).

Note that we do not multiply ${ }^{14} R$ by ${ }^{14} R_{\text {std }}$ in Eq. (1), as we are using a normalized $\mathrm{DI}^{14} \mathrm{C}$ (following Orr et al., 2000). Given that this abiotic implementation does not account for the fractionation during gas exchange, we do not apply the correction for fractionation that is commonly applied to observational measurements of ${ }^{14} \mathrm{C} /{ }^{12} \mathrm{C}$ ratios (as well as for the biotic ${ }^{14} \mathrm{C}$ implementation; see Eq. (27) in Sect. 3.2.4). The simulated abiotic $\Delta^{14} \mathrm{C}$ is therefore directly comparable to observed data reported as $\Delta^{14} \mathrm{C}$ (see Toggweiler et al., 1989, for more details).

\subsubsection{Surface fluxes}

We follow the abiotic OCMIP-2 protocol (Orr et al., 2000) for most of the implementation of the abiotic radiocarbon surface fluxes, with the following notable differences.

- We use a coefficient $a$ of $0.31 \mathrm{~cm} \mathrm{~h}^{-1}$ (Wanninkhof, 1992) instead of $0.337 \mathrm{cmh}^{-1}$ as used in OCMIP-2. This is higher than what most recent estimates suggest (e.g., Sweeney et al., 2007; Naegler et al., 2006; Naegler, 2009; Graven et al., 2012), but makes it consistent with the gas-transfer formulation used in other parts of the CESM.

- We use the daily mean of the squared $10 \mathrm{~m}$ wind speed (either from the prescribed CORE-II forcing or from the coupled atmospheric model) instead of the climatology of the squared monthly average of the instantaneous SSMI velocity and its instantaneous variance as used in OCMIP-2.

- We use the daily mean of the ice fraction and atmospheric pressure (either from the data models or the coupled sea ice and atmosphere models) instead of the monthly averaged climatology used in OCMIP-2.

- We use a constant reference value $\left(1944 \mu \mathrm{mol} \mathrm{m}^{-3}\right)$ for the virtual fluxes of abiotic radiocarbon, rather than an annually updated average of the surface $\mathrm{DI}^{14} \mathrm{C}$ as suggested in OCMIP-2. This is done to conserve total ${ }^{14} \mathrm{C}$ in the model (in the absence of radioactive decay).

To compute the partial pressure of $\mathrm{CO}_{2}$ from the abiotic $\mathrm{DI}^{12} \mathrm{C}$, we require an estimate of surface alkalinity. We follow again OCMIP-2, i.e., we estimate surface alkalinity (Alk) by scaling the ocean mean alkalinity, Alkbar = 2310 microeq $\mathrm{kg}^{-1}$ with sea-surface salinity, SSS, i.e.,

$\mathrm{Alk}=\mathrm{Alkbar} \cdot \rho_{\mathrm{sw}} \cdot \mathrm{SSS} / S_{\text {Ref }}$

with $S_{\text {Ref }}=34.7$ and $\rho_{\mathrm{sw}}=4.1 / 3.996 \mathrm{~g} \mathrm{~cm}^{-3}$ (these two are constants in the CESM). We alter this calculation in the Baltic Sea and the Black Sea to avoid unrealistic alkalinity values, following the procedure developed by K. Lindsay for creating initial conditions for the marine ecosystem model: in the Black Sea, the surface alkalinity is independent of SSS: alkalinity $=3300 \cdot \rho_{\mathrm{sw}}$. In the Baltic Sea, we calculate alkalinity depending on the surface salinity, with alkalinity $=119+196 \cdot$ SSS when SSS is equal to or below 7.3, and alkalinity $=1237+43 \cdot$ SSS when the SSS is above 7.3. The computation of $p \mathrm{CO}_{2}$ also requires an assumption about the surface ocean concentrations of silicic acid and phosphate, for which we use OCMIP-2's global constants, i.e., $7.5 \mu \mathrm{mol} \mathrm{kg}{ }^{-1}$ for silicic acid, $\mathrm{Si}(\mathrm{OH})_{4}$, and $0.5 \mu \mathrm{mol} \mathrm{kg}-1$ for phosphate, $\mathrm{PO}_{4}$.

\section{Air-sea gas exchange}

As in OCMIP-2, the air-sea gas exchange flux of ${ }^{12} \mathrm{C}$ is calculated as

$F=\mathrm{PV} \cdot\left(C_{\text {sat }}-C_{\text {surf }}\right)$

with $\mathrm{PV}$ being the $\mathrm{CO}_{2}$ gas transfer velocity (called the piston velocity) in $\mathrm{m} \mathrm{s}^{-1}$, calculated as

$\mathrm{PV}=(1-$ aice $) \cdot a \cdot u_{10}^{2} \cdot\left(660.0 / S c_{\mathrm{CO}_{2}}\right)^{-1 / 2}$.

The coefficient $a$ is taken as $0.31 \mathrm{~cm} \mathrm{~h}^{-1}$ as mentioned earlier, aice is the fraction of the ocean covered by sea ice, $u_{10}^{2}$ is the squared $10 \mathrm{~m}$ wind speed from the coupler, and $S c_{\mathrm{CO}_{2}}$ is the Schmidt number of $\mathrm{CO}_{2} . S c_{\mathrm{CO}_{2}}$ is calculated as in the ecosystem model, following Wanninkhof (1992):

$$
\begin{aligned}
S c_{\mathrm{CO}_{2}}= & 2073.1+\mathrm{SST} \cdot(-125.62+\mathrm{SST} \\
& \cdot(3.6276+\mathrm{SST} \cdot(-0.043219))) .
\end{aligned}
$$

$C_{\text {surf }}$ in the gas flux calculation above is the surface aqueous $\mathrm{CO}_{2}$ concentration in mol m${ }^{-3}$ (also called $\mathrm{CO}_{2}^{*}$, which is the aqueous $\mathrm{CO}_{2}$ concentration in $\mathrm{mol} \mathrm{m}^{-3}$ in the ocean 
in general). $C_{\mathrm{sat}}$ is the saturation concentration in $\mathrm{molm}^{-3}$, with $C_{\text {sat }}=\mathrm{CO}_{2}^{*}+\mathrm{DCO}_{2}^{*}$ and $\mathrm{DCO}_{2}^{*}$ being the difference in $\mathrm{CO}_{2}$ concentration between the surface ocean and the atmosphere. SST is the sea surface temperature. $\mathrm{CO}_{2}^{*}$ and $\mathrm{DCO}_{2}^{*}$ in turn are calculated by the carbonate solver from the ecosystem model, based on SST, SSS, ALK, $\mathrm{PO}_{4}, \mathrm{Si}(\mathrm{OH})_{4}, \mathrm{pH}$, atmospheric $p \mathrm{CO}_{2}$, atmospheric pressure, and the abiotic $\mathrm{DI}^{12} \mathrm{C}$ and $\mathrm{DI}^{14} \mathrm{C}$ concentrations in the surface water.

As in OCMIP-2, we do not account for fractionation during gas exchange in this abiotic formulation, as the effect of isotopic fractionation is almost completely accounted for by the standard correction made when calculating $\Delta^{14} \mathrm{C}$ from observations (see Toggweiler et al., 1989, for details).

The gas flux of the normalized abiotic $\mathrm{DI}^{14} \mathrm{C}$ is calculated as

$F^{14}=\mathrm{PV} \cdot\left(\mathrm{C}_{\mathrm{sat}} \cdot R^{14} \mathrm{C}_{\mathrm{atm}}-\mathrm{C}_{\mathrm{surf}} \cdot R^{14} \mathrm{C}_{\mathrm{ocn}}\right)$

with

$R^{14} \mathrm{C}_{\mathrm{atm}}=\left(1+\Delta^{14} \mathrm{C}_{\mathrm{atm}} / 1000\right)$

and

$R^{14} \mathrm{C}_{\mathrm{ocn}}=1000 \cdot\left(\mathrm{DI}^{14} \mathrm{C} / \mathrm{DI}^{12} \mathrm{C}-1\right)$.

The values of the atmospheric $p \mathrm{CO}_{2}$ and $\Delta^{14} \mathrm{C}_{\text {atm }}$ can be set to be constants or can be read in from a file. For atmospheric $p \mathrm{CO}_{2}$, it can also be taken from the coupler, to ensure the use of a consistent atmospheric $p \mathrm{CO}_{2}$ value across model components. Currently the code is set up to read in three files of $\Delta^{14} \mathrm{C}_{\mathrm{atm}}$ values, one each for the Northern Hemisphere, the equatorial region $\left(20^{\circ} \mathrm{N}-20^{\circ} \mathrm{S}\right)$, and the Southern Hemisphere, in order to represent the spatial inhomogeneity of $\Delta{ }^{14} \mathrm{C}_{\mathrm{atm}}$, for example, after the atmospheric nuclear bomb tests.

\section{Virtual fluxes}

The CESM ocean model is a volume-conserving model where water fluxes at the surface (from precipitation, evaporation, and river input) are added as virtual fluxes. These virtual fluxes represent the dilution or concentration effect from adding or removing freshwater. For the abiotic carbon isotope tracers, we have a virtual $\mathrm{DI}^{12} \mathrm{C}$ and $\mathrm{DI}^{14} \mathrm{C}$ flux. As for salinity and for DIC in the ecosystem model, we use a constant surface reference $\mathrm{DI}^{12} \mathrm{C}$ and $\mathrm{DI}^{14} \mathrm{C}$ for the calculation of virtual fluxes in order to conserve tracers. The reference values are $1944 \mu \mathrm{mol} \mathrm{m}{ }^{-3}$ for both $\mathrm{DI}^{12} \mathrm{C}$ and normalized $\mathrm{DI}^{14} \mathrm{C}$, the same as for DIC in the ecosystem model of CESM.

\subsubsection{Interior processes}

In the interior of the ocean, the only additional term to the transport of the tracers by the physical ocean model is the decay term for $\mathrm{DI}^{14} \mathrm{C}$, following the OCMIP-2 protocol:

$\mathrm{d}\left[\mathrm{DI}^{12} \mathrm{C}\right] / \mathrm{d} t=L\left(\left[\mathrm{DI}^{12} \mathrm{C}\right]\right)$ and

$\mathrm{d}\left[\mathrm{DI}^{14} \mathrm{C}\right] / \mathrm{d} t=L\left(\left[\mathrm{DI}^{14} \mathrm{C}\right]\right)-\lambda \cdot\left[\mathrm{DI}^{14} \mathrm{C}\right]$,

with $L$ being the 3-D transport operator and $\lambda$ being the radioactive decay constant for ${ }^{14} \mathrm{C}$ in $\mathrm{s}^{-1}$, using a half-life of 5730 years (Godwin, 1962):

$\lambda=\ln (2) /(5730 \cdot 31556926)$.

The radiocarbon age (relative to $\mathrm{AD} 1950=0 \mathrm{yr} \mathrm{BP}$ ) is calculated from $\Delta^{14} \mathrm{C}$ following

${ }^{14} \mathrm{C}_{\mathrm{age}}=-5730 / \ln 2 \times \ln \left(1+\Delta{ }^{14} \mathrm{C} / 1000\right)$.

5730 years $/ \ln 2=8267$ years is the mean life of ${ }^{14} \mathrm{C}$, which differs from the often used mean life of 8033 years (e.g., Stuiver and Polach, 1977), which is based on the earlier Libby half-life of 5568 (Libby, 1955).

\subsection{Biotic ${ }^{13} \mathrm{C}$ and ${ }^{14} \mathrm{C}$}

In the biotic implementation of ${ }^{13} \mathrm{C}$ and ${ }^{14} \mathrm{C}$, we use the ocean ecosystem model (e.g., Moore et al., 2013) to compute the carbon pools as well as all other biological variables (like silicic acid and alkalinity). The ecosystem model currently has seven carbon pools: DIC, DOC (dissolved organic carbon), $\mathrm{CaCO}_{3}$, diazotrophs, diatoms, small phytoplankton, and zooplankton. We carry passive tracers for each of these in the isotope-enabled version of the code. As ${ }^{12} \mathrm{C}$ makes up over $98 \%$ of the carbon earth and does not fractionate, we assume that the ecosystem carries ${ }^{12} \mathrm{C}$. This means that the isotope ratio $R$ can be calculated as the ratio of the new isotopic carbon pools to the ecosystem carbon pools. As for the abiotic radiocarbon, we use scaled variables for ${ }^{13} \mathrm{C}$ and ${ }^{14} \mathrm{C}$ in order to minimize the numerical error of carrying very small numbers (particularly for ${ }^{14} \mathrm{C}$ ). The scaling factor is the commonly used standard ${ }^{\text {iso }} \mathrm{C} /{ }^{12} \mathrm{C}$ for each isotope, i.e., $1.12372 \times 10^{-8}$ for iso $={ }^{13} \mathrm{C}$ (Craig, 1957) and $1.176 \times 10^{-12}$ for iso $={ }^{14} \mathrm{C}$ (Karlen et al., 1968). This means that we use ${ }^{13} R_{\mathrm{Std}}=1$ and ${ }^{14} R_{\mathrm{Std}}=1$ in the code, and that the model-simulated isotopic carbon pools are multiplied by the respective scaling factor to compare them with observations.

In the biotic formulation, we account for the fractionation of ${ }^{13} \mathrm{C}$ and ${ }^{14} \mathrm{C}$ during gas exchange and during biological processes. The fractionation $(\epsilon)$ of ${ }^{14} \mathrm{C}$ is always twice that of ${ }^{13} \mathrm{C}$, as all relevant processes have a mass-dependent fractionation for carbon (Bigeleisen, 1952; Craig, 1954). The isotopic fractionation $\epsilon$ is related to the fractionation factor $\alpha$ through

$\epsilon=(\alpha-1) \cdot 1000$.

As diagnostic variables, we compute the $\delta^{\text {iso }} \mathrm{C}$ values by first computing the ratio ${ }^{\text {iso }} R=\mathrm{DI}^{\text {iso }} \mathrm{C} / \mathrm{DIC}$ and then using

$\delta^{\text {iso }} \mathrm{C}=\left({ }^{\text {iso }} R-1\right) \cdot 1000$. 
As for the abiotic $\Delta^{14} \mathrm{C}$ calculation in Eq. (1), we do not multiply by iso $R_{\text {Std }}$ in the calculation of $\delta^{\text {iso }} \mathrm{C}$ because we are using normalized $\mathrm{DI}^{\mathrm{iso}} \mathrm{C}$.

\subsubsection{Air-sea gas exchange of ${ }^{13} \mathrm{C}$}

The air-sea flux of ${ }^{13} \mathrm{C}$ is calculated based on Zhang et al. (1995):

$$
\begin{aligned}
F^{13}= & \mathrm{PV} \cdot \alpha_{\mathrm{aq}_{\mathrm{g}}} \cdot \alpha_{\mathrm{k}} \\
& \cdot\left(R^{13} \mathrm{C}_{\mathrm{atm}} \cdot \mathrm{C}_{\mathrm{sat}}-R^{13} \mathrm{C}_{\mathrm{DIC}} \cdot \mathrm{C}_{\mathrm{surf}} / \alpha_{\mathrm{DIC}_{\mathrm{g}}}\right) .
\end{aligned}
$$

Here, $\mathrm{C}_{\mathrm{sat}}$ and $\mathrm{C}_{\mathrm{surf}}$ are obtained from the ecosystem model. $\alpha_{\mathrm{k}}=-0.99919$ is the constant kinetic fractionation factor from Zhang et al. (1995) (with $\epsilon=-0.81$ and $\alpha=$ $\epsilon / 1000+1) . \alpha_{\mathrm{aqg}_{\mathrm{g}}}$ is the temperature (TEMP, in ${ }^{\circ} \mathrm{C}$ ) dependent isotopic fractionation factor during gas dissolution, based on the equation for $\epsilon_{\mathrm{aq}_{\mathrm{g}}}$ from Zhang et al. (1995):

$\epsilon_{\mathrm{aq}_{\mathrm{g}}}=-0.0049 \cdot \mathrm{TEMP}-1.31$.

The temperature and carbonate fraction $\left(f_{\mathrm{CO}_{3}}\right)$ dependent fractionation factor $\left(\alpha_{\mathrm{DIC}_{\mathrm{g}}}\right)$ between total DIC and $\mathrm{CO}_{2}$ is based on the empirical relationship for $\epsilon_{\mathrm{DIC}_{\mathrm{g}}}$ from Zhang et al. (1995):

$\epsilon_{\mathrm{DIC}_{\mathrm{g}}}=0.014 \cdot \mathrm{TEMP} \cdot f_{\mathrm{CO}_{3}}-0.105 \cdot \mathrm{TEMP}+10.53$.

$R{ }^{13} \mathrm{C}_{\text {atm }}$ is the ${ }^{13} \mathrm{C}$ to ${ }^{12} \mathrm{C}$ ratio in atmospheric $\mathrm{CO}_{2}$, calculated using the atmospheric $\delta^{13} \mathrm{C}_{\mathrm{atm}}$ record and $R_{\mathrm{atm}}=$ $1+\delta^{13} \mathrm{C}_{\mathrm{atm}} / 1000$ (scaled by ${ }^{13} R_{\mathrm{Std}}$ ). The values of $\delta^{13} \mathrm{C}_{\mathrm{atm}}$ can be set to be a constant or it can be read in from a file. Currently $\delta^{13} \mathrm{C}_{\text {atm }}$ is assumed to be well mixed globally, so only one global value is read in. With small code modifications globally inhomogeneous $\delta^{13} \mathrm{C}_{\mathrm{atm}}$ values can easily be read in instead. $R^{13} \mathrm{C}_{\text {DIC }}$ is the ${ }^{13} \mathrm{C}$ to ${ }^{12} \mathrm{C}$ ratio of dissolved inorganic carbon, calculated from the simulated biotic DIC and $\mathrm{DI}^{13} \mathrm{C}$.

\subsubsection{Virtual fluxes of ${ }^{13} \mathrm{C}$}

As stated in Sect. 3.1, we account for the dilution and concentration effect of surface freshwater fluxes in the model by adding a virtual flux, using a constant surface reference $\mathrm{DI}^{13} \mathrm{C}$ (and DI ${ }^{14} \mathrm{C}$ ) of $1944 \mu \mathrm{molm}{ }^{-3}$ for the calculation of virtual fluxes.

\subsubsection{Biological fractionation of ${ }^{13} \mathrm{C}$}

The isotopic carbon fixation by photosynthesis (photo ${ }^{13} \mathrm{C}$ ) is computed from the ${ }^{12} \mathrm{C}$ fixation during photosynthesis (photoC, from the ecosystem model), using

photo ${ }^{13} \mathrm{C}=$ photoC $\cdot R_{\mathrm{p}}$

with

$R_{\mathrm{p}}=1000 \cdot R_{\mathrm{CO}_{2}^{*}} /\left(\epsilon_{\mathrm{p}}+1000\right)$
Table 1. Parameters used in the parameterization of $\epsilon_{\mathrm{p}}$ for the implementation following Keller and Morel (1999). The values for small phytoplankton are based on E. huxleyi, the value for diatoms are based on P. tricornumtum, and the values for diatoms are based on Synechococcus sp. (Keller and Morel, 1999; Popp et al., 1998).

\begin{tabular}{lccc}
\hline & Small phytoplankton & Diatom & Diazotroph \\
\hline Qc $\left(\right.$ molCcell $\left.^{-1}\right)$ & $69.2 \times 10^{-14}$ & $63.3 \times 10^{-14}$ & $3 \times 10^{-14}$ \\
cell $_{\text {permea }}\left(\mathrm{m} \mathrm{s}^{-1}\right)$ & $1.8 \times 10^{-5}$ & $3.3 \times 10^{-5}$ & $3.0 \times 10^{-8}$ \\
cell $_{\text {surf }}\left(\mathrm{m}^{2}\right)$ & $87.6 \times 10^{-12}$ & $100.6 \times 10^{-12}$ & $5.8 \times 10^{-12}$ \\
$\mathrm{C}_{\text {up }}$ & 2.2 & 2.3 & 7.5 \\
$\epsilon_{\text {fix }}$ & 25.3 & 26.6 & 30 \\
\hline
\end{tabular}

and

$R_{\mathrm{CO}_{2}^{*}}=R^{13} \mathrm{C}_{\mathrm{DIC}} \cdot \alpha_{\mathrm{aq}_{\mathrm{g}}} / \alpha_{\mathrm{DIC}_{\mathrm{g}}}$.

The strength of the biological fractionation of carbon during photosynthesis $\left(\epsilon_{\mathrm{p}}\right)$, as well as the key controlling parameters, are still being debated in the literature (e.g., Keller and Morel, 1999), and many of the existing ${ }^{13} \mathrm{C}$ implementations in models use different parameterizations. We therefore implemented three different parameterizations for $\epsilon_{\mathrm{p}}$ to test the sensitivity of our results to the choice of biological fractionation.

The simplest model for $\epsilon_{\mathrm{p}}$ by Rau et al. (1989) gives the same $\epsilon_{\mathrm{p}}$ value for all types of autotrophs:

$\epsilon_{\mathrm{p}}=1000 \cdot\left(\delta_{\mathrm{CO}_{2}^{*}}-\delta_{C_{\mathrm{p}}}\right) /\left(1000+\delta_{\mathrm{C}_{\mathrm{p}}}\right)$.

This relationship is based on the empirical relationship found by Rau et al. (1989) between the isotopic composition of the autotroph $\left(\delta_{\mathrm{C}_{\mathrm{p}}}\right)$ and $\mathrm{CO}_{2}^{*}$ :

$\delta_{\mathrm{C}_{\mathrm{p}}}=-0.8 \cdot \mathrm{CO}_{2}^{*}-12.6$,

limiting $\delta_{\mathrm{C}_{\mathrm{p}}}$ to values between -18 and $-32 \%$ o (Rau et al., 1989).

Laws et al. (1995) assumed that $\mathrm{CO}_{2}$ enters the cell by diffusion and that the fractionation depends on the rate of photosynthesis, and therefore parameterized $\epsilon_{\mathrm{p}}$ as a function of $\mathrm{CO}_{2}^{*}$ and the specific photosynthesis rate of each phytoplankton group ( $\mu$, in $\mathrm{s}^{-1}$, calculated by the ecosystem model):

${ }^{13} \epsilon_{\mathrm{p}}=\left(\mu / \mathrm{CO}_{2}^{*} \cdot 86400-0.371\right) /(-0.015)$.

Keller and Morel (1999) argued that only considering diffusive $\mathrm{CO}_{2}$ transport into cells and assuming a linear relationship between $\epsilon_{\mathrm{p}}$ and $\mathrm{CO}_{2}^{*}$ concentration and the specific growth rate $(\mu)$ does not agree with laboratory and field data, citing work by Sikes et al. (1980), Tortell et al. (1997), and Laws et al. (1997). Keller and Morel (1999) therefore proposed to use phytoplankton type-specific (constant) cell parameters (see Table 1) to compute the fractionation during photosynthesis:

${ }^{13} \epsilon_{\mathrm{p}}=\epsilon_{\mathrm{diff}}+\left(\mathrm{C}_{\mathrm{up}} /\left(\mathrm{C}_{\mathrm{up}}+1 / \mathrm{var}\right)\right) \cdot \delta_{\mathrm{d} 13 \mathrm{C}}+\theta \cdot\left(\epsilon_{\mathrm{fix}}-\epsilon_{\mathrm{diff}}\right)$ 
where

$\theta=\left(1+\left(\mathrm{C}_{\mathrm{up}}-1\right) \cdot \operatorname{var}\right) /\left(1+\mathrm{C}_{\mathrm{up}} \cdot \operatorname{var}\right)$

and

$\operatorname{var}=\mu / \mathrm{CO}_{2}^{*} \cdot 1000 \cdot \mathrm{Qc} /\left(\right.$ cell $_{\text {permea }} \cdot$ cell $\left._{\text {surf }}\right)$,

with Qc being the cell carbon content, cell permea $_{\text {being the }}$ cell wall permeability to $\mathrm{CO}_{2}(\mathrm{aq})$, cell $1_{\text {surf }}$ being the surface areas of cells, $\mathrm{C}_{\text {up }}$ being the ratio of active carbon uptake to carbon fixation, $\epsilon_{\text {fix }}$ being a constant phytoplankton typedependent fractionation effect of carbon fixation, $\epsilon_{\text {diff }}=0.7$ representing the fractionation by diffusion (O'Leary, 1984), and $\delta_{\mathrm{d} 13 \mathrm{C}}=-9.0$ being the difference between the isotopic compositions of the external $\mathrm{CO}_{2}$ and the organic matter pools (Goericke et al., 1994).

While the fractionation during calcium carbonate formation is much smaller than the fractionation during photosynthesis (Turner, 1982), we include a small constant fractionation of $2 \%$ for calcium carbonate formation, based on work by Ziveri et al. (2003) that found a range of $3 \%$ to $-2 \%$ o for different species. Other implementations of ${ }^{13} \mathrm{C}$ in ocean models have used values of $1 \%$ (e.g., Sonnerup et al., 1999; Tagliabue and Bopp, 2008) or have assumed no isotopic fractionation for calcification (e.g., Marchal et al., 1998; Schmittner et al., 2013). However, as shown by Schmittner et al. (2013), the effect of the calcium carbonate pump on $\delta^{13} \mathrm{C}$ is small, so the choice of the value for the fractionation during calcium carbonate formation is not expected to have a big impact on the results in the current ecosystem model with one species of calcium carbonate.

\subsubsection{Biotic ${ }^{14} \mathrm{C}$}

The ${ }^{14} \mathrm{C}$ air-sea flux is calculated in the same way as shown in Eq. (15) for ${ }^{13} \mathrm{C}$, but with the fractionation for ${ }^{14} \mathrm{C}$ being twice as large as for ${ }^{13} \mathrm{C}\left(\epsilon_{14}=2 \cdot \epsilon_{13}\right.$, Zeebe and WolfGladrow, 2001) and with $R^{14} \mathrm{C}_{\mathrm{atm}}$ and $R^{14} \mathrm{C}_{\mathrm{DIC}}$ instead of $R^{13} \mathrm{C}_{\mathrm{atm}}$ and $R^{13} \mathrm{C}_{\mathrm{DIC}}$. The biological fractionation is also the same as for ${ }^{13} \mathrm{C}$, except that $\epsilon_{14}=2 \cdot \epsilon_{13}$ everywhere in Sect. 3.2.3. The surface reference value for $\mathrm{DI}^{14} \mathrm{C}$ for the virtual flux calculation is $1944 \mu \mathrm{mol} \mathrm{m}{ }^{-3}$, the same as for DI ${ }^{13} \mathrm{C}$ (and $\mathrm{DI}^{12} \mathrm{C}$ ).

In contrast to ${ }^{13} \mathrm{C},{ }^{14} \mathrm{C}$ decays in all carbon pools, following the decay equation (see Eq. (11) in Sect. 3.1.2).

To compare the model-simulated $\delta^{14} \mathrm{C}$ values that we save as diagnostics (see Eq. 14) with published observations of $\Delta^{14} \mathrm{C}$, we apply the same fractionation correction to it that is used for observations to convert $\delta^{14} \mathrm{C}$ to $\Delta^{14} \mathrm{C}$ :

$\Delta^{14} \mathrm{C}=\delta^{14} \mathrm{C}-2\left(\delta^{13} \mathrm{C}+25\right)\left(1+\delta^{14} \mathrm{C} / 1000\right)$.

In the following we always show $\Delta^{14} \mathrm{C}$.

As for the abiotic ${ }^{14} \mathrm{C}$ implementation, the value of $\Delta{ }^{14} \mathrm{C}_{\mathrm{atm}}$ can be set to be a constant or it can be read in from three files (one for the Northern Hemisphere, one for the equatorial region, and one for the Southern Hemisphere).

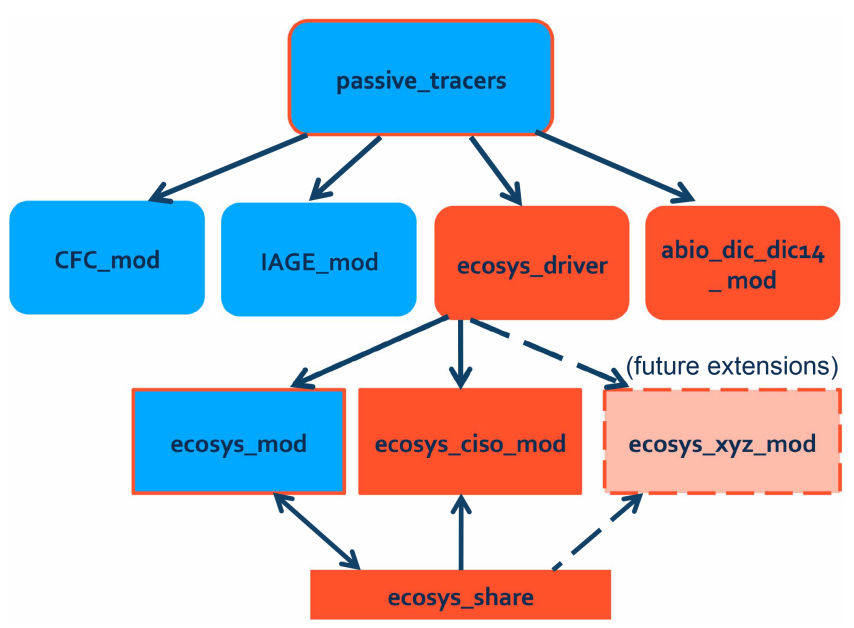

Figure 1. Schematic of the passive tracer modules with the new ecosystem driver and carbon isotope modules. Existing modules are shown in blue, new modules are shown in red, and edited modules are shown in blue with a red box. Dashed lines indicate future developments. This schematic shows how the ecosystem driver acts as an interface between the ecosystem-related modules and the passive tracers module that drives all tracer modules as well as how ecosys_share is used to share variables computed by the ecosystem model and used by other modules beside the ecosystem model.

\subsection{Ecosystem driver}

We added an ecosystem driver (ecosys_driver) to the ocean model of the CESM in order to make it easier to expand the model to carry additional passive tracers that require variables from the ecosystem model, without adding these additional tracers to the ecosystem model itself. The ecosystem driver is structured similarly to the passive_tracers subroutine that calls all passive tracer modules, but it handles only the passive tracers that use the ecosystem model (see Fig. 1). It is called from the passive_tracers subroutine, and determines how many ecosystem-related passive tracers the model carries based on the namelist options set at buildtime. It then calls all subroutines in the ecosystem model and the related tracer modules, after being called by passive tracers with the corresponding tracer indices. Variables computed in the ecosystem model but used by other modules are shared via the new ecosys_share module. Only the ecosystem model changes the value of the variables in ecosys_share at this point. Other modules currently only read them from there, but do not modify them. With this infrastructure in place, additional tracers can be easily added without changing the ecosystem model too much. The only changes to the ecosystem model should be the copying of ecosystem variables to ecosys_share if they need to be shared with a new module as well as potentially the addition of new definitions and calculations of derived ecosystem variables that are needed 
but that are not currently computed in the ecosystem model (or not present in the required format, i.e., defined as local 2 -D variables instead of a global 3-D variable). Nitrogen isotopes in the ocean model have already been added using this infrastructure (S. Yang, personal communication, 2014).

\section{Results}

\subsection{Simulations and spin-up}

We have performed several simulations with the new carbonisotope-enabled model. As described in Sect. 2, we used the ocean-only version of the CESM1.0.5, at a nominal $3^{\circ}$ horizontal resolution, forced by CORE-II climatological forcing (Large and Yeager, 2009). To spin up the carbon isotopes, we performed spin-up simulations that lasted several thousands of years. Radiocarbon takes a long time (5000-15000 years, according to Orr et al., 2000) to equilibrate, due to the long timescale of deep ocean ventilation.

The abiotic radiocarbon has been spun up for 10000 years using an atmospheric $\mathrm{CO}_{2}$ concentration of $284.7 \mathrm{ppm}$ and a $\Delta^{14} \mathrm{C}$ value of $0 \%$. The abiotic $\mathrm{DI}^{14} \mathrm{C}$ and $\mathrm{DI}^{12} \mathrm{C}$ were started from the standard ecosystem initial conditions, scaled to yield a global initial state of $0 \% \circ \Delta^{14} \mathrm{C}$ (following Orr et al., 2000), in order to simplify early interpretation and code verification. After 10000 simulated years, the models satisfy the OCMIP2 surface $\mathrm{CO}_{2}$ flux criterion of less than $0.01 \mathrm{PgC}_{\text {year }}{ }^{-1}$. In terms of the drift in $\Delta^{14} \mathrm{C}, 91 \%$ of the ocean volume is spun up to the OCMIP2 criterion of a drift of less than $0.001 \%$ year $^{-1}$ (compared to the required $98 \%$ for OCMIP2). Compared to the fully spun-up solution (obtained using a new online Newton-Krylov method, manuscript in preparation by K. Lindsay, NCAR), differences are seen in the deep ocean only.

For the biotic carbon isotopes, we spun up the carbon isotopes for 6010 years, starting from the initial conditions of the ecosystem model, scaled to give a $\delta^{13} \mathrm{C}$ of $0 \%$ and a $\Delta^{14} \mathrm{C}$ of $-100 \%$. The atmospheric $\mathrm{CO}_{2}$ concentration was set to $284.7 \mathrm{ppm}$, the atmospheric $\Delta^{14} \mathrm{C}$ was set to $0 \%$, and the atmospheric $\delta^{13} \mathrm{C}$ was set to $-6.379 \%$. In order to study the different biological fractionation parameterizations, two additional spin-up simulations were branched from the first spin-up simulation at year 2560 and run to year 6010. After 6010 years, the surface $\mathrm{CO}_{2}$ flux is well below the OCMIP2 criterion of less than $0.01 \mathrm{PgCyear}^{-1}$, and over $99.99 \%$ of the ocean volume shows a drift of less than $0.001 \%$ year $^{-1}$ in $\delta^{13} \mathrm{C}$. However, only $26 \%$ of the ocean satisfies the OCMIP2 criterion of a drift of less than $0.001 \%$ year $^{-1}$ for $\Delta^{14} \mathrm{C}$. Another 4000 years or more are likely required to get the biotic $\Delta^{14} \mathrm{C}$ fully spun-up according to the OCMIP2 criterion. However, if we weaken the OCMIP2 criterion by an order of magnitude to less than $0.01 \%$ year $^{-1}, 99.98 \%$ of the ocean satisfies this new criterion for $\Delta^{14} \mathrm{C}$. Due to the long time required to run the ocean model with the ecosystem and the biotic carbon isotopes (the 6010 years took over 7 months of constant running on a supercomputer), we are currently not able to run the biotic radiocarbon to full equilibrium. In order to reach equilibrium in the future, a fast spin-up technique for the ecosystem model is currently in development by Keith Lindsay and will be applied to the biotic carbon isotopes when it is ready. We believe that for the purpose of this paper, which documents the implementation of the carbon isotopes in the model, the current spin-up is sufficient, in particular because future science applications will use the fully coupled $1^{\circ} \mathrm{CESM}$, rather than the $3^{\circ}$ ocean-only model version used here for model development. For these future science applications, the biotic radiocarbon should be spun up further in order to be fully trustworthy, and the carbon isotope simulation should be carefully validated in this model configuration.

After the long spin-up, we then performed experiments from 1765 to 2008, with the initial conditions from the end of the spin-up simulations in year 6010 for the biotic carbon isotopes and in year 10000 for the abiotic radiocarbon. The atmospheric $\mathrm{CO}_{2}, \Delta^{14} \mathrm{C}$, and $\delta^{13} \mathrm{C}$ were prescribed based on the OCMIP-2 files (Orr et al., 2000) up to 1989 , and H. Graven's formulation of the global average for 1990-2008 (personal communication, 2012). The atmospheric state was the same repeating climatological CORE-II forcing as used for the spin-up, so changes related to warming or changes in the wind forcing over the 20th century are not included. We continued with the climatological COREII forcing rather than use the interannually varying CORE-II forcing for 1948-2007 in order to avoid shocks to the ocean when switching the forcing and when the forcing jumps from 2007 back to 1948 every 60 years. This jump in the forcing impacts the simulation for 10 years or more (as described in Danabasoglu et. al., 2014), and would overlap with the start of the introduction of bomb radiocarbon into the atmosphere.

We also continued the spin-up simulations for 243 years, so that we could remove the influence of any continuing drift on the radiocarbon results shown in Sect. 4.2.2. To investigate the influence of the net $\mathrm{CO}_{2}$ uptake on the simulation results in the second part of the 20th century, we also performed sensitivity experiments where the atmospheric $\mathrm{CO}_{2}$ was fixed at 1949 conditions, while $\Delta^{14} \mathrm{C}_{\mathrm{atm}}$ and $\delta^{13} \mathrm{C}_{\mathrm{atm}}$ changed as usual.

\section{2 ${ }^{14} \mathrm{C}$ results}

\subsubsection{Simulated distributions of $\Delta^{14} \mathrm{C}$}

The radiocarbon simulation shows good agreement with the gridded GLODAP data for the 1990s (Key et al., 2004), reflecting the main features of the $\Delta^{14} \mathrm{C}$ distribution: (i) at the surface (see Fig. 2) the model shows the observed $M$ shape of $\Delta^{14} \mathrm{C}$ distribution, with the highest values in the relatively stable subtropical waters, intermediate values in the equatorial upwelling zone, and low values in the polar regions, 


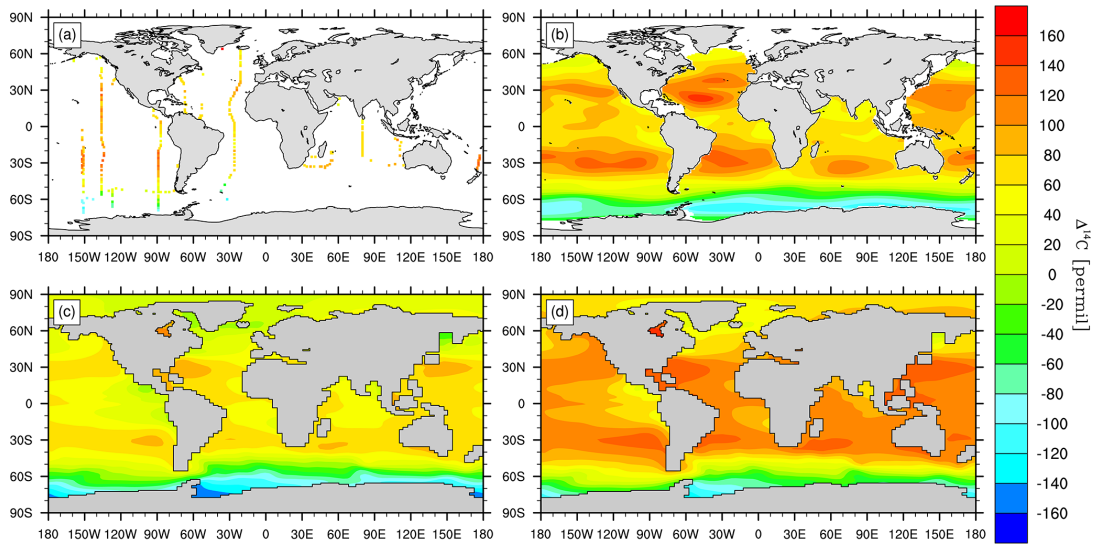

Figure 2. Surface values of total $\Delta^{14} \mathrm{C}$ from the 1990s (including bomb ${ }^{14} \mathrm{C}$ ) from (a) cruise data compiled by Schmittner et al. (2013), (b) the gridded GLODAP data (Key et al., 2004), (c) simulated biotic $\Delta^{14} \mathrm{C}$, and (d) simulated abiotic $\Delta^{14} \mathrm{C}$.

where the residence time is short and sea ice limits the uptake of atmospheric $\Delta^{14} \mathrm{C}$, with the overall lowest values in the Southern Ocean, where the upwelling of old, low $\Delta^{14} \mathrm{C}$ waters further dilutes the surface waters. (ii) In the zonal mean (see Fig. 3), newly formed deepwater with high $\Delta^{14} \mathrm{C}$ values can clearly be separated from old water masses with low $\Delta^{14} \mathrm{C}$ values. (iii) In the depth profiles (see Fig. 4), it is obvious that the $\Delta^{14} \mathrm{C}$ in the deep water decreases from the Atlantic Ocean over the Indian Ocean to the Pacific Ocean, which has the lowest $\Delta^{14} \mathrm{C}$ values (i.e., oldest water). Consistently, the abiotic $\Delta{ }^{14} \mathrm{C}$ values are higher than the biotic $\Delta^{14} \mathrm{C}$ values, but both show the same general features also shown in GLODAP (Key et al., 2004) and in the cruise data compiled by Schmittner et al. (2013) because their distribution is set mainly by the physical ocean simulation. The difference between the abiotic and biotic simulations due to biological effects has been estimated to be on the order of $10 \%$ (Fiadiero, 1982), but since the biotic radiocarbon simulation is less spun-up than the abiotic simulation at this point, a detailed investigating of the impact of the biological effects is premature and will be the topic of a future study when we can spin up both radiocarbon implementations using a fast-spin up technique.

Above $1000 \mathrm{~m}$, the depth structure of the simulated $\Delta^{14} \mathrm{C}$ agrees reasonably well with observations, with the best agreement with the GLODAP $\Delta^{14} \mathrm{C}$ in the upper $250 \mathrm{~m}$ of the Indian Ocean (see Fig. 4). The largest biases are found at depths below $1000 \mathrm{~m}$ (see Fig. 4), with the model showing $\Delta{ }^{14} \mathrm{C}$ values that are too negative (i.e., water that is too old). The largest bias is located in the deep Pacific, where the $\Delta{ }^{14} \mathrm{C}$ is up to $100 \%$ o too negative (see Figs. 3 and 4 ). In terms of radiocarbon age, the maximum bias in the deep Pacific is 1000 years compared to GLODAP, revealing that the deep Pacific Ocean in the model is not ventilated as much as it should be. This is a well-known bias in the CESM, which was also present in the ocean model of a previous version of the CESM, the CCSM3 (Graven et al., 2012), as well as in the nominal $1^{\circ}$ resolution version of the current CESM1 ocean model (Bardin et al., 2014), and is related to too weak Antarctic Bottom Water formation in the CESM (Danabasoglu et. al., 2011) and too shallow mixed layers in the Southern Ocean (Moore et al., 2013). Currently radiocarbon is being used to test improvements to the ventilation in the Southern Ocean in the ocean model in the CESM, in order to improve this bias in future versions of the CESM (K. Lindsay, personal communication, 2014).

\subsection{2 ${ }^{14} \mathrm{C}$ bomb inventory}

The excess oceanic radiocarbon inventory is frequently used to investigate the ocean uptake of anthropogenic carbon (e.g., Key et al., 2004; Graven et al., 2012) and to determine the mean gas exchange velocity used in ocean models (e.g., Wanninkhof, 1992; Sweeney et al., 2007; Naegler et al., 2006; Naegler, 2009). To establish how well the newly developed radiocarbon tracer compares to observations, we here compare the simulated excess radiocarbon inventory with observational estimates. The excess radiocarbon in the ocean includes change in the oceanic radiocarbon from the atmospheric nuclear bomb tests of the 1950s and 1960s, as well as from the Suess effect and changes in net $\mathrm{CO}_{2}$ uptake, compared to the reference period of the 1940s, following Naegler (2009). In 1975, the excess radiocarbon inventory in the abiotic and biotic simulation is $297 \times 10^{26}$ atoms ${ }^{14} \mathrm{C}$ and $295 \times 10^{26}$ atoms ${ }^{14} \mathrm{C}$, respectively. This lies within the range of observational estimates of the excess radiocarbon in 1975 , which range from $225 \times 10^{26}$ atoms ${ }^{14} \mathrm{C}$ to $314 \pm 35 \times 10^{26}$ atoms ${ }^{14} \mathrm{C}$ (see Table 2). It has been shown that the earlier estimates from Broecker et al. $(1985,1995)$ were high by about $25 \%$ (e.g., Hesshaimer et al., 1994; Peacock, 2004; Sweeney et al., 2007), which suggests that the simulated values are probably on the high end of the observational range. One reason for this could be the choice of the coefficient $a=0.31 \mathrm{~cm} \mathrm{~h}^{-1}$ in Eq. (3), which has been shown 


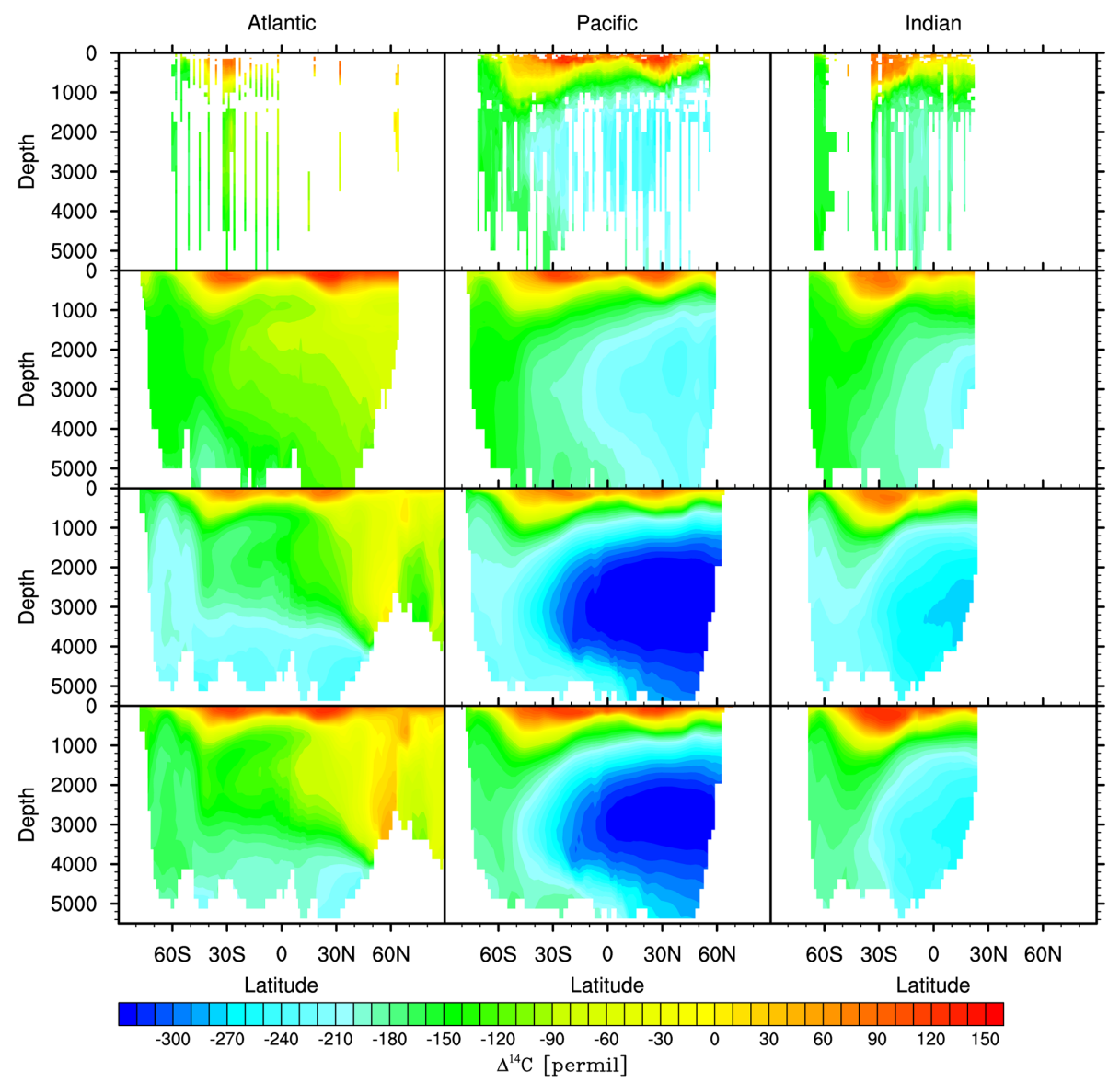

Figure 3. Zonal averages of total $\Delta^{14} \mathrm{C}$ for the Atlantic, Pacific, and Indian oceans for the 1990s, from cruise data compiled by Schmittner et al. (2013) (top row), the gridded GLODAP data (Key et al., 2004) (second row), the $\Delta^{14} \mathrm{C}$ from the biotic model (third row), and the abiotic model (bottom row). Note that due to the sparse observational data (see Fig. 2a for the coverage at the surface), the zonal average from the cruise data in the top row is more of a zonal composite than a zonal average.
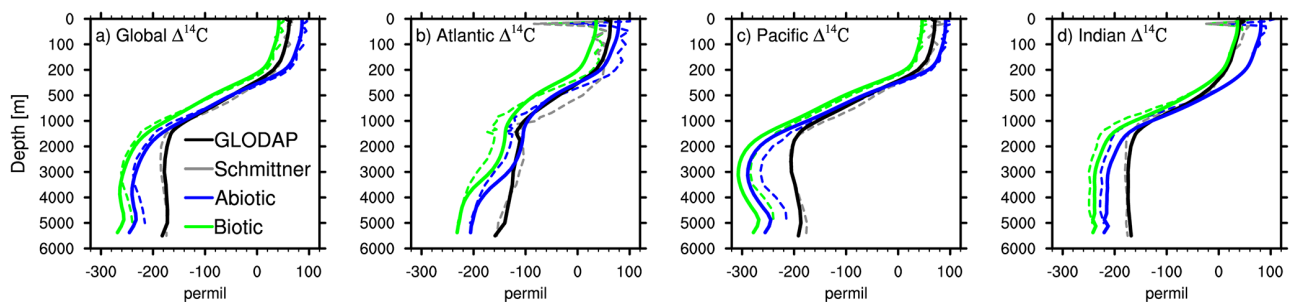

Figure 4. Depth profiles of $\Delta^{14} \mathrm{C}$ for (a) the global ocean, (b) the Atlantic Ocean, (c) the Pacific Ocean, and (d) the Indian Ocean. The simulated biotic (green) and abiotic (blue) $\Delta^{14} \mathrm{C}$ is compared to the global gridded GLODAP $\Delta^{14} \mathrm{C}$ (black) data set (Key et al., 2004). In addition, dashed lines show the cruise data compiled by Schmittner et al. (2013) (gray) and the model-simulated data subsampled at the same locations as these data (green and blue dashed lines).

to be high (e.g., Sweeney et al., 2007; Naegler, 2009). Graven et al. (2012) showed that in the ocean model of the CCSM3, the simulated excess radiocarbon inventory was lower when a coefficient $a=0.23 \mathrm{~cm} \mathrm{~h}^{-1}$ rather than $a=0.31 \mathrm{~cm} \mathrm{~h}^{-1}$ was used in Eq. (3). However, since $a=0.31 \mathrm{~cm} \mathrm{~h}^{-1}$ is the parameter used in the CESM in general to compute air-sea gas fluxes, we did not change it here. For 1995, the excess ra- diocarbon inventories in the abiotic and biotic simulation are $389 \times 10^{26}$ atoms ${ }^{14} \mathrm{C}$ and $390 \times 10^{26}$ atoms ${ }^{14} \mathrm{C}$, respectively, which is close to but slightly higher than the observational estimates of $313-383 \times 10^{26}$ atoms ${ }^{14} \mathrm{C}$ (see Table 2).

The natural radiocarbon inventory, before anthropogenic disturbances from the Suess effect and from increased oceanic net $\mathrm{CO}_{2}$ uptake, has been estimated to be $19000 \pm$ 
Table 2. Excess oceanic radiocarbon inventory, measured in $10^{26}$ atoms of ${ }^{14} \mathrm{C}$, from various sources for 1975 (GEOSECS) and 1995 (WOCE). Corrections by Naegler et al. (2006) are for neglected ocean regions; corrections by Naegler (2009) are for neglected contributions from increasing DIC. The values from this study are listed at the bottom, for the abiotic and biotic implementation. The biotic excess radiocarbon inventories are the same for all biological fractionation choices tested.

\begin{tabular}{lcc}
\hline Publication & 1975 (GEOSECS) & 1995 (WOCE) \\
\hline Broecker et al. (1980) & $314 \pm 35$ & \\
Broecker et al. (1985) & 289 & \\
Lassey et al. (1990) & 303 & \\
Hesshaimer et al. (1994) & 225 & \\
Broecker and Peng (1994) & 300 & \\
Broecker et al. (1995) & $305 \pm 30$ & \\
Peacock (2004) multitracer correlation & $241 \pm 60$ & $335 \pm 15$ \\
Corrected by Naegler et al. (2006) & $245 \pm 60$ & $340 \pm 15$ \\
Corrected by Naegler (2009) & $252 \pm 60$ & $367 \pm 15$ \\
Peacock (2004) silicate approach & $262 \pm 26$ & \\
Corrected by Naegler et al. (2006) & $264 \pm 26$ & \\
Key et al. (2004) & & $313 \pm 47$ \\
Corrected by Naegler et al. (2006) & & $355 \pm 50$ \\
Corrected by Naegler (2009) & & $383 \pm 50$ \\
Naegler and Levin (2006) & $258 \pm 13$ & $367 \pm 17$ \\
Sweeney et al. (2007) & 225 & $343 \pm 40$ \\
Corrected by Naegler (2009) & 232 & $370 \pm 40$ \\
Naegler (2009) & & $373 \pm 98$ \\
This study, abiotic ${ }^{14}$ C & 297 & 389 \\
This study, biotic ${ }^{14} \mathrm{C}$ & 295 & 390 \\
\hline
\end{tabular}

$1200 \times 10^{26}$ atoms of ${ }^{14} \mathrm{C}$ (Naegler, 2009). In the simulation the inventory is just outside the error bar for the biotic model (17 763-17 770 $\times 10^{26}$ atoms of ${ }^{14} \mathrm{C}$, depending on the biological fractionation used), and slightly lower for the abiotic model $\left(16190 \times 10^{26}\right.$ atoms of $\left.{ }^{14} \mathrm{C}\right)$. The natural radiocarbon inventories are calculated for years 6185-6194 of the control simulations, which corresponds to the same total run time as years 1940-1949 in the 1765-2008 experiments, which were started from the control in year 6010 . However, the biotic model estimate of the natural radiocarbon inventory might still not be the final value, as the biotic radiocarbon is still spinning up. In terms of the anthropogenic radiocarbon inventories presented next, this biases should not play any large role, however, as we remove any remaining drift. Specifically, to calculate the early anthropogenic radiocarbon inventory present in the 1940s, we take the difference between the natural radiocarbon inventory in simulation years 61856194 (with constant atmospheric $\mathrm{CO}_{2}, \Delta{ }^{14} \mathrm{C}$, and $\delta^{14} \mathrm{C}$ ) and the inventory in the 1940s (with changing atmospheric $\mathrm{CO}_{2}$, $\Delta^{14} \mathrm{C}$, and $\delta^{14} \mathrm{C}$ since 1765). By taking this difference between years of equal total run time, we remove the impact of any remaining drift in $\Delta^{14} \mathrm{C}$. We find an anthropogenic radiocarbon inventory of $20 \times 10^{26}$ atoms of ${ }^{14} \mathrm{C}$ for the abiotic model and $5 \times 10^{26}$ atoms of ${ }^{14} \mathrm{C}$ for the biotic model (independent of the biological fractionation used). Both of these anthropogenic radiocarbon inventories for the 1940s are within the error bar of the estimate of $4 \pm 20 \times 10^{26}$ of
${ }^{14} \mathrm{C}$ from Naegler (2009), with the biotic model giving a very good match.

Using sensitivity experiments from 1950 to 2008 with atmospheric $\mathrm{CO}_{2}$ held constant at 1949 levels but normally increasing atmospheric $\Delta^{14} \mathrm{C}$, we can calculate the impact of increased ocean uptake of anthropogenic $\mathrm{CO}_{2}$ on the excess radiocarbon inventory: in 1975, the excess oceanic radiocarbon inventory relative to the 1940 s due to atmospheric $\Delta{ }^{14} \mathrm{C}$ changes alone (from the atmospheric bomb tests and the Suess effect) is $282 \times 10^{26}$ atoms of ${ }^{14} \mathrm{C}$ for the abiotic model and $280 \times 10^{26}$ atoms of ${ }^{14} \mathrm{C}$ for the biotic model, while for 1995 the numbers are $353 \times 10^{26}$ atoms of ${ }^{14} \mathrm{C}$ and $354 \times 10^{26}$ atoms of ${ }^{14} \mathrm{C}$, respectively. This means that the increase in net $\mathrm{CO}_{2}$ uptake contributed $15 \times 10^{26}$ atoms of ${ }^{14} \mathrm{C}$ in 1975 and $36 \times 10^{26}$ atoms of ${ }^{14} \mathrm{C}$ in 1995 compared to the 1940s (for both the abiotic and biotic models), which is 5 and $9 \%$ of the total radiocarbon excess in these years, respectively. These changes are in excellent agreement with calculations from Naegler (2009), which showed an excess radiocarbon inventory in 1995 of $346 \pm 98 \times 10^{26}$ atoms ${ }^{14} \mathrm{C}$ due to atmospheric $\Delta^{14} \mathrm{C}$ changes, and $27 \pm 9 \times 10^{26}$ atoms ${ }^{14} \mathrm{C}$ due to net $\mathrm{CO}_{2}$ uptake. The percentage contribution of the net $\mathrm{CO}_{2}$ uptake to the total radiocarbon excess was given as $3 \%$ in 1975 and $8 \%$ in 1995 in Naegler (2009), which again compares very well with our model simulation. 


\section{3 ${ }^{13} \mathrm{C}$ results}

\subsubsection{Simulated $\delta^{13} \mathrm{C}$ and the impact of different biological fractionation parameterizations}

In the literature, models of biological fractionation are still under debate (e.g., Keller and Morel, 1999). We therefore tested three different parameterizations of biological fractionation, to investigate the impact on the simulated $\delta^{13} \mathrm{C}$ (as described in Sects. 3.2.3 and 4.1). As shown in Fig. 5a, the simulated globally averaged $\epsilon_{\mathrm{p}}$ depth profiles differ when these different parameterizations are used, with $\epsilon_{\mathrm{p}}$ values ranging from 15 to 30 . By design, $\epsilon_{\mathrm{p}}$ is the same for diatoms, diazotrophs, and small phytoplankton when using Rau et al. (1989), while $\epsilon_{\mathrm{p}}$ shows large variations between species for the method of Keller and Morel (1999), due to the dependence on species-specific cell parameters (see Table 1). The method of Laws et al. (1995) leads to small differences between species in the surface ocean only. Below $200 \mathrm{~m}$, only the $\epsilon_{\mathrm{p}}$ following Rau et al. (1989) still changes with depth (see Fig. 5a), due to the sole dependence of $\epsilon_{\mathrm{p}}$ on $\mathrm{CO}_{2}^{*}$ and the export of organic carbon and carbonates to depth.

The impact of the different biological fractionation choices on $\delta^{13} \mathrm{C}_{\text {DIC }}$ is noticeable (see Fig. 5b), with the globally averaged $\delta^{13} C_{\text {DIC }}$ based on $\epsilon_{\mathrm{p}}$ from Rau et al. (1989) being larger below $150 \mathrm{~m}$ compared to the $\delta^{13} \mathrm{C}_{\text {DIC }}$ from Laws et al. (1995) and Keller and Morel (1999), but slightly smaller at the surface. Despite the more complex formulation of $\epsilon_{\mathrm{p}}$ in Keller and Morel (1999) compared to Laws et al. (1995) and the significantly different $\epsilon_{\mathrm{p}}$ profiles, the resulting $\delta^{13} \mathrm{C}_{\text {DIC }}$ from both methods is very similar and only differs slightly at depth (most notably between 150 and $2000 \mathrm{~m}$ ). To compare the simulated $\delta^{13} \mathrm{C}_{\mathrm{DIC}}$ to the cruise data of $\delta^{13} \mathrm{C}_{\mathrm{DIC}}$ compiled by Schmittner et al. (2013), we re-gridded the model output to subsample the model at the same points as covered by the cruise data. The resulting globally averaged depth profiles are shown in Fig. 5c, and are remarkably similar to the full globally averaged model results in Fig. 5b. Both show the expected increase in $\delta^{13} \mathrm{C}_{\text {DIC }}$ directly below the surface, due to the preferential uptake of the light isotope during photosynthesis, followed by the expected decrease in $\delta^{13} \mathrm{C}_{\mathrm{DIC}}$ with depth due to the remineralization of the isotopically light organic material back into the water column. The modelsimulated global depth profile of $\delta^{13} \mathrm{C}_{\text {DIC }}$ lies within the error range of $\pm 0.2 \%$ around the cruise $\delta^{13} \mathrm{C}_{\mathrm{DIC}}$ data between the surface and $150 \mathrm{~m}$ and below $1000 \mathrm{~m}$, but shows smaller $\delta^{13} \mathrm{C}_{\text {DIC }}$ values than observed between 150 and $1000 \mathrm{~m}$.

For individual basins, the model bias compared to the cruise data is smallest in the Atlantic, with the $\delta^{13} \mathrm{C}_{\text {DIC }}$ based on the biological fractionation from Rau et al. (1989) almost entirely within the uncertainty range of the data (see Fig. 5d). All three basins contribute to the bias seen between 150 and $2000 \mathrm{~m}$ in the global average, with the Indian Ocean contributing the most to this bias in the upper ocean and the Pacific Ocean contributing the most at intermediate depths (see
Fig. 5c-f). In general, the model simulated $\delta^{13} \mathrm{C}_{\text {DIC }}$ tends to be smaller than the observed $\delta^{13} \mathrm{C}_{\text {DIC }}$. While the difference between the full global average in the model and the subset global average based on the cruise data locations is small, the difference between the total basin average (shown as dashed lines in Fig. 5d-f) and the subset basin averages (shown as solid lines) is larger for the individual basins.

At the surface, the simulated $\delta^{13} \mathrm{C}_{\text {DIC }}$ values show a systematic bias in that they are generally larger than the observational data suggest, but the same general spatial pattern is visible (see Fig. 6). While both gas-exchange and biological processes are important for the surface ocean $\delta^{13} \mathrm{C}_{\text {DIC }}$ pattern (Schmittner et al., 2013), the details of the biological fractionation parameterizations appear to have a very small impact at the surface, as shown in the almost identical surface distributions from the model (see Fig. 6c-e). The zonal means of $\delta^{13} \mathrm{C}_{\mathrm{DIC}}$ from the different biological fractionation parameterizations on the other hand do show some small differences (see Fig. 7), with the biological fractionation from Rau et al. (1989) leading to the largest $\delta^{13} C_{\text {DIC }}$ values in all three ocean basins, while the fractionation based on Keller and Morel (1999) shows the lowest $\delta^{13} \mathrm{C}_{\text {DIC }}$ values. Overall, all three parameterizations lead to the expected pattern of high values of $\delta^{13} \mathrm{C}_{\mathrm{DIC}}$ in water that has recently been in contact with the surface (e.g., North Atlantic Deep Water) and low $\delta^{13} \mathrm{C}_{\mathrm{DIC}}$ values in water that has been out of contact with the atmosphere for a long period of time and has accumulated a large amount of remineralized (isotopically light) organic mater (e.g., in the deep Pacific).

We choose the biological formulation from Laws et al. (1995) as the default biological fractionation in our model, as it considers the growth rate of different species, but the differences in the simulated $\delta^{13} \mathrm{C}_{\mathrm{DIC}}$ compared to the more complex formulation from Keller and Morel (1999) are small. The other parameterizations of biological fractionation remain an option in the model that can be chosen at build time.

\subsubsection{Oceanic surface ${ }^{13} \mathrm{C}$ Suess effect}

The surface oceanic Suess effect, which is the decrease in the surface ocean $\delta^{13} \mathrm{C}$ due to the penetration of carbon originating from the burning of fossil fuels, has been calculated from observational data as well as from other models that include ${ }^{13} \mathrm{C}$, and it is often used to derive the oceanic anthropogenic carbon uptake (e.g., McNeil et al., 2001; Tagliabue and Bopp, 2008). In our model simulation, the surface $\delta^{13} \mathrm{C}$ change between 1975 and 1995 is -0.164 to $-0.167 \%$ odecade ${ }^{-1}$ (the range is for the different biological fractionations used). This compares well with other estimates of $-0.171 \%$ odecade ${ }^{-1}$ (Bacastow et al., 1996), $-0.18 \%$ odecade d $^{-1}$ (Gruber et al., 1999), $-0.15 \%$ o decade ${ }^{-1}$ (Sonnerup et al., 1999), and $-0.174 \%$ odecade ${ }^{-1}$ (Tagliabue and Bopp, 2008). As already shown by Quay et al. (1992) and Gruber et al. (1999), the surface ocean Suess effect is not uniform (see Fig. 8), and the model simulation of the spatial 

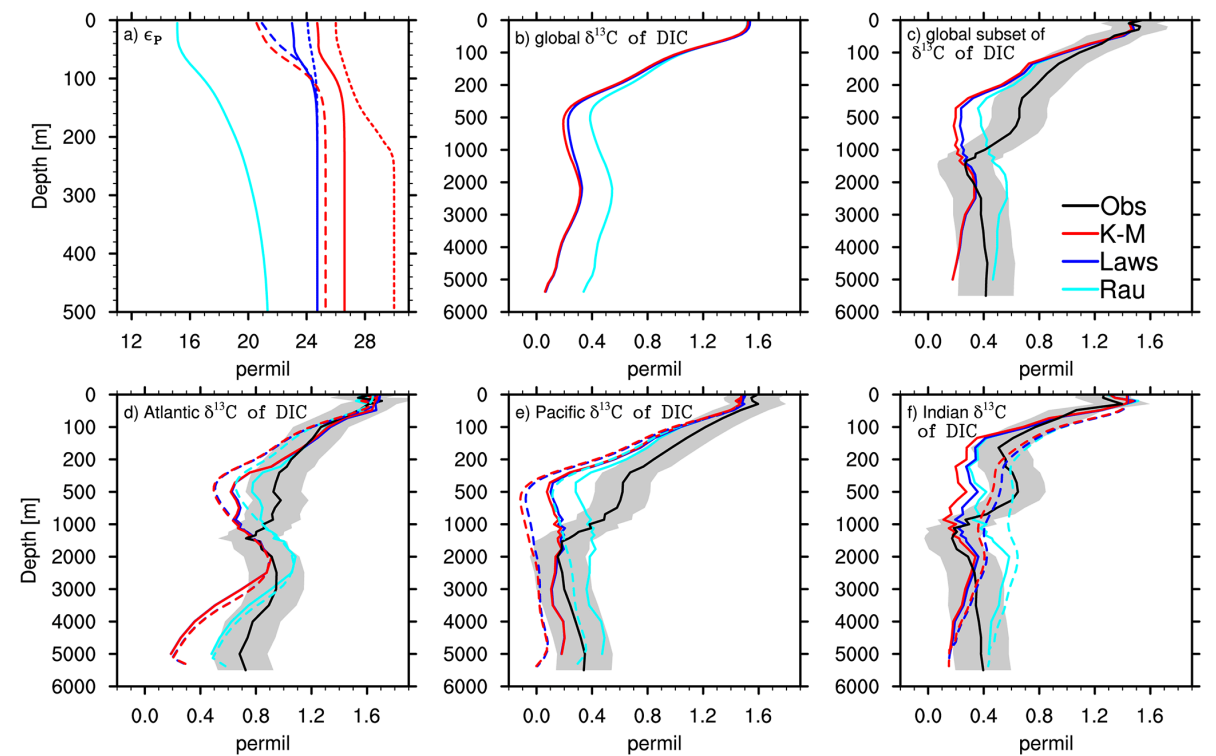

Figure 5. (a) Depth profiles over the top $500 \mathrm{~m}$ (where $\epsilon_{\mathrm{p}}$ is important because of primary production) of the globally averaged values of $\epsilon_{\mathrm{p}}$ produced by the three tested parameterizations for biological fractionation for diatoms (solid line), diazotrophs (short dashes), and small phytoplancton (large dashes). The simulated globally averaged depth profile $(0-6000 \mathrm{~m})$ of $\delta^{13} \mathrm{C}_{\mathrm{DIC}}$ in the $1990 \mathrm{~s}$ is shown in (b), and the global average depth profile of the subset model $\delta^{13} \mathrm{C}_{\text {DIC }}$ for the same grid points as in the cruise data compiled by Schmittner et al. (2013) is shown in (c). Basin average depth profiles are shown in (d-f), with dashed lines showing the full basin average from the model and solid lines showing the subset averages for the same points as the cruise data compiled by Schmittner et al. (2013). The uncertainty for the cruise data is shown as gray shading in (c), and is $\pm 0.2 \%$ (Schmittner et al., 2013). Note that the irregular $y$ axis in (b-f) emphasizes the upper ocean.
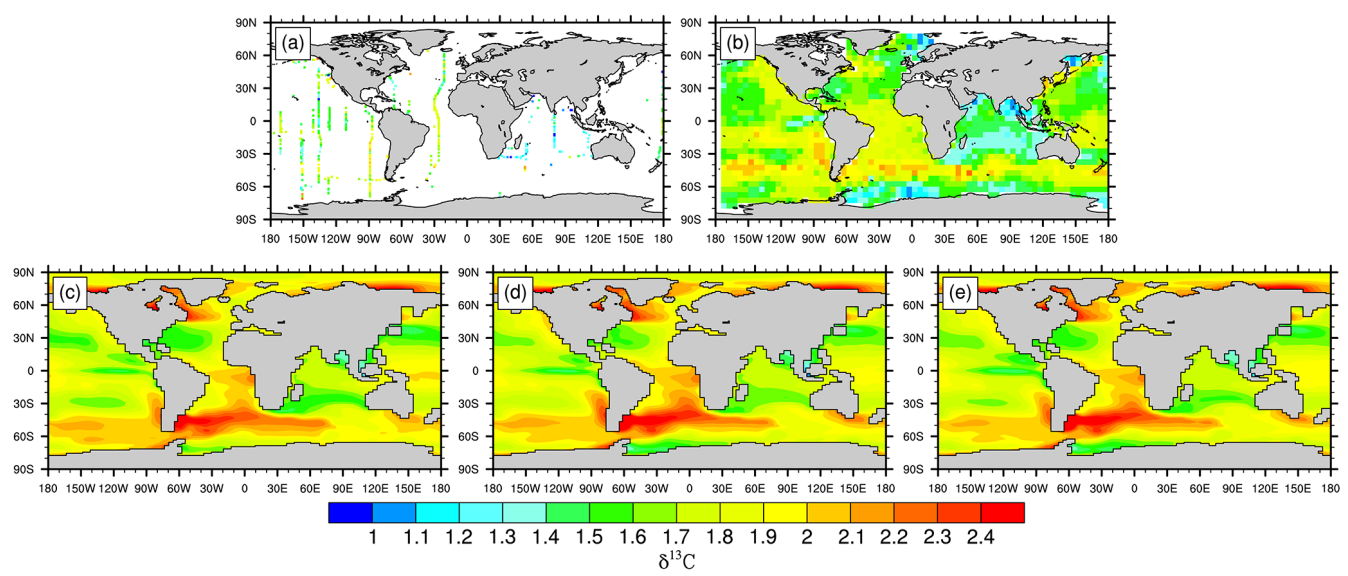

Figure 6. Surface values of $\delta^{13} \mathrm{C}$ for the 1990s from (a) cruise data compiled by Schmittner et al. (2013), (b) $5^{\circ}$ extrapolated gridded data from Gruber and Keeling (1999) and Gruber and Keeling (2001), and (c-e) the biotic model, using the biological fractionation from (c) Rau et al. (1989), (d) Laws et al. (1995), and (e) Keller and Morel (1999).

Suess effect agrees well with the model results of Tagliabue and Bopp (2008): the largest changes (i.e., most negative values in Fig. 8) occur in regions with little deep ventilation and therefore longer residence times of water at the surface (e.g., the subtropical gyres), while the smallest changes (i.e., least negative or zero in Fig. 8) occur in regions of reduced airsea gas exchange (e.g., under sea ice), in regions with active deep convection (and therefore short residence times at the surface, e.g., around the Antarctic), as well as in regions with upwelling (which dilutes the surface $\delta^{13} \mathrm{C}$, for example, off the western coast of South America).

Compared to the pre-industrial ocean, the total surface ocean ${ }^{13} \mathrm{C}$ Suess effect is -0.064 to $-0.065 \%$ odecade ${ }^{-1}$ for 1860-2000 (depending on the different biological fractionations used), compared to $-0.07 \%$ odecade ${ }^{-1}$ found by Tagliabue and Bopp (2008). The fact that the simulated oceanic 


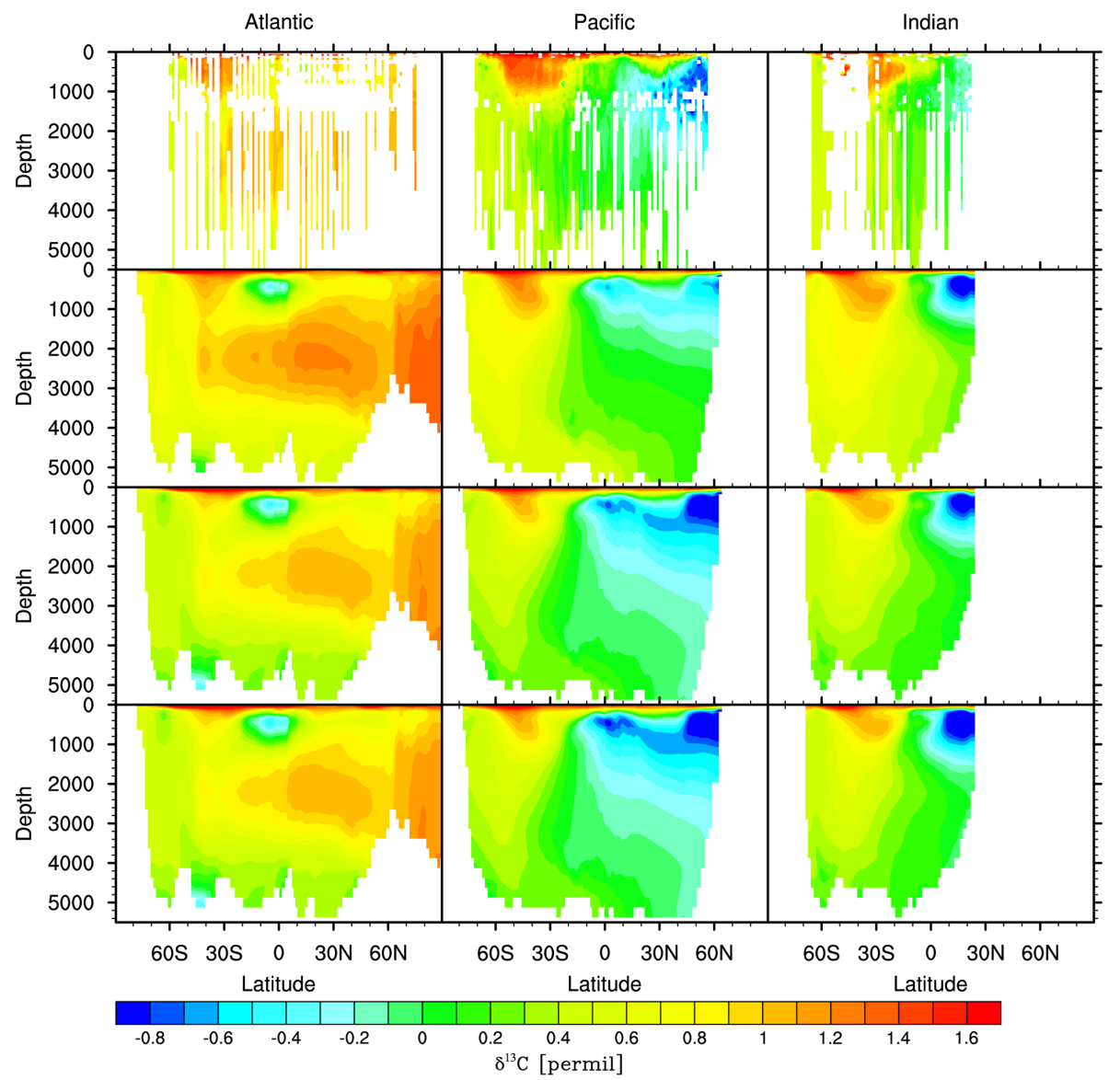

Figure 7. Zonal ocean basin composites from the cruise data compiled by Schmittner et al. (2013) (top row) compared to 1990s zonal basin averages from the model simulation using the biological fractionation from Rau et al. (1989) (second row), Laws et al. (1995) (third row), and Keller and Morel (1999) (bottom row).

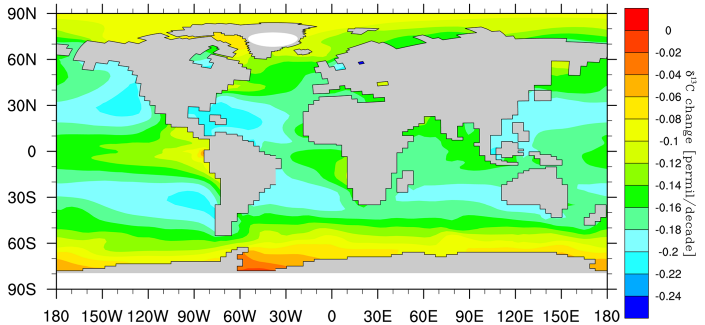

Figure 8. Surface ocean Suess effect (the change in $\delta^{13} \mathrm{C}$ ) between 1970 and 1990 , in \%odecade ${ }^{-1}$.

${ }^{13} \mathrm{C}$ Suess effect calculated over different periods agrees reasonably well with other available estimates suggests that our model is able to simulate the change in the oceanic $\delta^{13} \mathrm{C}$ inventory correctly, despite some mean biases in the distribution of $\delta^{13} \mathrm{C}$ described and shown in Sect. 4.3.1.

\section{Summary}

We have developed carbon isotope tracers in the ocean model of the CESM, including a biotic and an abiotic radiocarbon tracer and a biotic ${ }^{13} \mathrm{C}$ tracer. The details of the implementation are described here in order to serve as a reference for future users of these new model features and/or for model developers planning to modify the code or add carbon isotopes to other ocean models. In particular, we tested three different formulations for the fractionation during phytoplankton growth that have been discussed in the literature, and show that the effect on the simulated $\delta^{13} \mathrm{C}$ in the ocean is relatively minor. A comparison of the simulation results from the coarse nominal $3^{\circ}$ resolution ocean model forced with climatological CORE-II atmospheric forcing and with present-day data for $\Delta^{14} \mathrm{C}$ and $\delta^{13} \mathrm{C}$ shows that the simulated carbon isotopes can represent the large-scale features of the observed distributions as well as the anthropogenic changes due to nuclear bomb tests and the burning of fossil fuels. The carbon isotopes also reflect some known model biases, for example too sluggish ventilation of the deep Pacific Ocean. Once 
a fast spin-up technique for the biotic carbon isotopes has been implemented, we are planning to further validate the carbon-isotope simulation in the fully coupled CESM framework at $1^{\circ}$ resolution. Ultimately, we plan to use the carbon isotopes for both present-day and paleo simulations in the fully coupled framework of the CESM at the standard nominal $1^{\circ}$ resolution in the ocean, in order to investigate details of changes in the ocean circulation over the 20th century, the last Millennium, and at the Last Glacial Maximum.

\section{Code availability}

The newly developed carbon isotope and ecosystem driver code for the CESM1.0.5 is included as supplementary material here. The carbon isotope code has been updated to the CESM1.2, and has been added to the ocean development trunk in the CESM SVN repository (as of version cesm13-beta10). It continues to be updated as the CESM evolves, and is targeted for public release as part of the CESM2 in 2016. At that point the code will be available through the CESM release website at https://www2.cesm.ucar.edu/ models/current. Prior to the release, developer access can already be applied for at https://www2.cgd.ucar.edu/sections/ cseg/development-code, subject to the CESM development guidelines.

\section{The Supplement related to this article is available online at doi:10.5194/gmd-8-2419-2015-supplement.}

Acknowledgements. A. Jahn was funded under the DOE SciDAC grant Development of an Isotope-Enabled CESM for Testing Abrupt Climate Changes (DE-SC0006744). We thank Michael Levy (NCAR) and David M. Hall (CU Boulder) for software engineering advice, Matt Long (NCAR) for helpful discussions, and Heather Graven (Scripps) for sharing her extensions of the OCMIP atmospheric $\Delta^{14} \mathrm{C}, \delta{ }^{13} \mathrm{C}$, and $\mathrm{CO}_{2}$ data with us. We also thank Guy Munhoven for serving as editor and two anonymous reviewers for their constructive comments on the discussion paper. NCAR is sponsored by the National Science Foundation. N. Gruber and X. Giraud acknowledge funding from ETH Zürich. Computing resources (ark:/85065/d7wd3xhc) were provided by the Climate Simulation Laboratory at NCAR's Computational and Information Systems Laboratory on Yellowstone (2012), sponsored by the National Science Foundation and other agencies. Data analysis was performed with NCL Version 6.2.0 (2014).

Edited by: G. Munhoven

\section{References}

Bacastow, R. B., Keeling, C. D., Lueker, T. J., Wahlen, M., and Mook, W. G.: The ${ }^{13} \mathrm{C}$ Suess Effect in the world surface oceans and its implications for oceanic uptake of $\mathrm{CO}_{2}$ : analysis of observations at Bermuda, Global Biogeochem. Cy., 10, 335-346, doi:10.1029/96GB00192, 1996.

Bardin, A., Primeau, F., and Lindsay, K.: An offline implicit solver for simulating prebomb radiocarbon, Ocean Model., 73, 45-58, doi:10.1016/j.ocemod.2013.09.008, 2014.

Bigeleisen, J.: The effects of isotopic substitutions on the rate of chemical reactions, J. Phys. Chem., 56, 823-828, 1952.

Broecker, W. S. and Peng, T.-H.: Stratospheric contribution to the global bomb radiocarbon inventory: model versus observation, Global Biogeochem. Cy., 8, 377-384, doi:10.1029/94GB00680, 1994.

Broecker, W. S., Peng, T. H., and Engh, R.: Modelling the carbon system, Radiocarbon, 22, 377-384, 1980.

Broecker, W. S., Peng, T.-H., Östlund, G., and Stuiver, M.: The distribution of bomb radiocarbon in the ocean, J. Geophys. Res, 90, 6953-6970, doi:10.1029/JC090iC04p06953, 1985.

Broecker, W. S., Sutherland, S., Smethie, W., Peng, T. H., and Östlund, G.: Oceanic radiocarbon: separation of the natural and bomb components, Global Biogeochem. Cy., 9, 263-288, doi:10.1029/95GB00208, 1995.

Craig, H.: Carbon 13 is plants and the relationship between carbon 13 and carbon 14 variations in nature, J. Geol., 62, 115-149, 1954.

Craig, H.: Isotopic standards for carbon and oxygen and correction factors for mass-spectrometric analysis of carbon dioxide, Geochim. Cosmochim. Ac., 12, 133-149, 1957.

Crucifix, M.: Distribution of carbon isotopes in the glacial ocean: a model study, Paleoceanography, 20, PA4020, doi:10.1029/2005PA001131, 2005.

Curry, W. B. and Oppo, D. W.: Glacial water mass geometry and the distribution of $\delta^{13} \mathrm{C}$ of $p \mathrm{CO}_{2}$ in the Western Atlantic Ocean, Paleoceanography, 20, PA1017, doi:10.1029/2004PA001021, 2005.

Danabasoglu, G., Bates, S. C., Briegleb, B. P., Jayne, S. R., Jochum, M., Large, W. G., Peacock, S., and Yeager, S. G.: The CCSM4 Ocean Component, J. Climate, 25, 1361-1389, doi:10.1175/JCLI-D-11-00091.1, 2012.

Danabasoglu, G., Yeager, S. G., Bailey, D., Behrens, E., Bentsen, M., Bi, D., Biastoch, A., Böning, C., Bozec, A., Canuto, V. M., Cassou, C., Chassignet, E., Coward, A. C., Danilov, S., Diansky, N., Drange, H., Farneti, R., Fernandez, E., Fogli, P. G., Forget, G., Fujii, Y., Griffies, S. M., Gusev, A., Heimbach, P., Howard, A., Jung, T., Kelley, M., Large, W. G., Leboissetier, A., Lu, J., Madec, G., Marsland, S. J., Masina, S., Navarra, A., George Nurser, A. J., Pirani, A., Salas y Melia, D., Samuels, B. L., Scheinert, M., Sidorenko, D., Treguier, A.-M., Tsujino, H., Uotila, P., Valcke, S., Voldoire, A., and Wang, Q.: North Atlantic simulations in Coordinated Ocean-ice Reference Experiments phase $\{\mathrm{II}\}$ (CORE-II). Part I: Mean states, Ocean Model., 73, 76-107, doi:10.1016/j.ocemod.2013.10.005, 2014.

Doney, S. C., Lindsay, K., Caldeira, K., Campin, J., Drange, H., Dutay, J., Follows, M., Gao, Y., Gnanadesikan, A., Gruber, N., Ishida, A., Joos, F., Madec, G., Maier-Reimer, E., Marshall, J., Matear, R., Monfray, P., Mouchet, A., Najjar, R., Orr, J., Plattner, G., Sarmiento, J., Schlitzer, R., Slater, R., Totterdell, I., Weirig, M., Yamanaka, Y., and Yool, A.: Evaluating global ocean 
carbon models: the importance of realistic physics, Global Biogeochem. Cy., 18, GB3017, doi:10.1029/2003GB002150, 2004.

Fiadiero, M. E.: Three-dimensional modeling of tracers in the deep Pacific Ocean: radiocarbon and the circulation, J. Mar. Res., 40, 537-550, 1982.

Galbraith, E. D., Kwon, E. Y., Gnanadesikan, A., Rodgers, K. B., Griffies, S. M., Bianchi, D., Sarmiento, J. L., Dunne, J. P., Simeon, J., Slater, R. D., Wittenberg, A. T., and Held, I. M.: Climate variability and radiocarbon in the CM2Mc Earth System Model, J. Climate, 24, 4230-4254, doi:10.1175/2011JCLI3919.1, 2011.

Godwin, H.: Half life of radiocarbon, Nature, 195, 984, doi:10.1038/195984a0, 1962

Goericke, R., Montoya, J. P., and Fry, B.: Physiology of isotopic fractionation in algae and cyanobacteria, in: Stable Isotopes in Ecology and Environmental Science, edited by: Lajtha, K. and Michener, R. H., Blackwell Scientific Publications, Oxford, 187221, 1994

Graven, H. D., Gruber, N., Key, R., Khatiwala, S., and Giraud, X.: Changing controls on oceanic radiocarbon: new insights on shallow-to-deep ocean exchange and anthropogenic $\mathrm{CO}_{2}$ uptake, J. Geophys. Res., 117, C10005, doi:10.1029/2012JC008074, 2012.

Gruber, N. and Keeling, C. D.: The isotopic air-sea disequilibrium and the oceanic uptake of $\mathrm{CO}_{2}$, in: Proceedings of the 2nd International Symposium $\mathrm{CO}_{2}$ in the oceans, NIS, Tsukuba, Japan, edited by: Nojiri, Y., CGER-I037, Center for Global Environmental Research, National Institute for Environmental Studies, 245-250, 1999.

Gruber, N. and Keeling, C.: An improved estimate of the isotopic air-sea disequilibrium of $\mathrm{CO}_{2}$ : implications for the oceanic uptake of anthropogenic $\mathrm{CO}_{2}$, Geophys. Res. Lett., 28, 555-558, 2001

Gruber, N., Keeling, C. D., Bacastow, R. B., Guenther, P. R., Leuker, T. J., Wahlen, M., Meijer, H. A. J., Mook, W. G., and Stocker, T. F.: Spatiotemporal patterns of carbon-13 in the global surface oceans and the oceanic Suess effect, Global Biogeochem. Cy., 13, 307-335, 1999.

Hesse, T., Butzin, M., Bickert, T., and Lohmann, G.: A model-data comparison of $\delta^{13} \mathrm{C}$ in the glacial Atlantic Ocean, Paleoceanography, 26, PA3220, doi:10.1029/2010PA002085, 2011.

Hesshaimer, V., Heimann, M., and Levin, I.: Radiocarbon evidence for a smaller oceanic carbon dioxide sink than previously believed, Nature, 370, 201-203, doi:10.1038/370201a0, 1994.

Hurrell, J., Holland, M. M., Ghan, P. R. G. S., Kushner, J.. K. P., Lamarque, J.-F., Large, W. G., D. Lawrence, D., Lindsay, K., Lipscomb, W. H., Long, M., Mahowald, N., Marsh, D., Neale, R., Rasch, P., Vavrus, S., Vertenstein, M., Bader, D., Collins, W. D., Hack, J. J., Kiehl, J., and Marshall, S.: The Community Earth System Model: a framework for collaborative research, B. Am. Meteorol. Soc., 94, 1339-1360, doi:10.1175/BAMS-D-1200121.1, 2013.

Karlen, I., Olsson, I. U., Kallburg, P., and Kilici, S.: Absolute determination of the activity of two ${ }^{14} \mathrm{C}$ dating standards, Ark. Geofys., 4, 465-471, 1968.

Keeling, C. D., Bacastow, R. B., and Tans, P. P.: Predicted shift in the ${ }^{13} \mathrm{C} /{ }^{12} \mathrm{C}$ ratio of atmospheric carbon dioxide, Geophys. Res. Lett., 7, 505-508, doi:10.1029/GL007i007p00505,1980.
Keller, K. and Morel, F. M. M.: A model of carbon isotopic fractionation and active carbon uptake in phytoplankton, Mar. Ecol.Prog. Ser., 182, 295-298, 1999.

Key, R. M., Kozyr, A., Sabine, C. L., Lee, K., Wanninkhof, R., Bullister, J. L., Feely, R. A., Millero, F. J., Mordy, C., and Peng, T.-H.: A global ocean carbon climatology: results from Global Data Analysis Project (GLODAP), Global Biogeochem. Cy., 18, GB4031, doi:10.1029/2004GB002247, 2004.

Large, W. G. and Yeager, S. G.: The global climatology of an interannually varying air-sea flux data set, Clim. Dynam., 33, 341364, doi:10.1007/s00382-008-0441-3, 2009.

Lassey, K. R., Manning, M. R., and O'Brien, B. J.: An overview of oceanic radiocarbon: its inventory and dynamics, CRC Rev. Aquatic Sci., 3, 117-146, 1990.

Laws, E. A., Popp, B. N., Bidigare, R. R., Kennicutt, M. C., and Macko, S. A.: Dependence of phytoplankton carbon isotopic composition on growth rate and $\left[\mathrm{CO}_{2}\right] \mathrm{aq}$ : theoretical considerations and experimental results, Geochim. Cosmochim. Ac., 59, 1131-1138, doi:10.1016/0016-7037(95)00030-4, 1995.

Laws, E. A., Bidigare, R. R., and Popp, B. N.: Effect of growth rate and $\mathrm{CO}_{2}$ concentration on carbon isotopic fractionation by the marine diatom Phaeodactylum tricornutum, Limnol. Oceanogr., 42, 1552-1560, 1997.

Libby, W. F.: Radiocarbon Dating, 2nd Edn., Univ. Chicago Press, 1955.

Marchal, O., Stocker, T. F., and Joos, F.: A latitude-depth, circulation-biogeochemical ocean model for paleoclimate studies. Development and sensitivities, Tellus B, 50, 290-316, doi:10.1034/j.1600-0889.1998.t01-2-00006.x, 1998.

Matsumoto, K., Sarmiento, J. L., Key, R. M., Aumont, O., Bullister, J. L., Caldeira, K., Campin, J., Doney, S. C., Drange, H., Dutay, J.-C., Follows, M., Gao, Y., Gnanadesikan, A., Gruber, N., Ishida, A., Joos, F., Lindsay, K., Maier-Reimer, E., Marshall, J., Matear, R., Monfray, P., Mouchet, A., Najjar, R., Plattner, G., Schlitzer, R., Slater, R., Swathi, P., Totterdell, I., Weirig, M., Yamanaka, Y., Yool, A., and Orr, J.: Evaluation of ocean carbon cycle models with data-based metrics, Geophys. Res. Lett., 31, L07303, doi:10.1029/2003GL018970, 2004.

McDermott, F.: Palaeo-climate reconstruction from stable isotope variations in speleothems: a review, Quaternary Sci. Rev., 23, 901-918, doi:10.1016/j.quascirev.2003.06.021, 2004.

McNeil, B. I., Matear, R. J., and Tilbrock, B.: Does carbon 13 track anthropogenic $\mathrm{CO}_{2}$ in the Southern Ocean?, Global Biogeochem. Cy., 15, 597-613, 2001.

Meissner, K. J.: Younger Dryas: a data to model comparison to constrain the strength of the overturning circulation, Geophys. Res. Lett., 34, L21705, doi:10.1029/2007GL031304, 2007.

Meissner, K. J., Schmittner, A., Weaver, A. J., and Adkins, J. F.: Ventilation of the North Atlantic Ocean during the Last Glacial Maximum: a comparison between simulated and observed radiocarbon ages, Paleoceanography, 18, 1023, doi:10.1029/2002PA000762, 2003.

Moore, J. K., Lindsay, K., Doney, S. C., Long, M. C., and Misumi, K.: Marine ecosystem dynamics and biogeochemical cycling in the Community Earth System Model [CESM1(BGC)]: comparison of the 1990s with the 2090s under the RCP4.5 and RCP8.5 scenarios, J. Climate, 26, 9291-9312, doi:10.1175/JCLID-12-00566.1, 2013. 
Naegler, T.: Reconciliation of excess ${ }^{14} \mathrm{C}$-constrained global $\mathrm{CO}_{2}$ piston velocity estimates, Tellus B, 61, 372-384, 2009.

Naegler, T. and Levin, I.: Closing the global radiocarbon budget 1945-2005, J. Geophys. Res., 111, D12311, doi:10.1029/2005JD006758, 2006.

Naegler, T., Ciais, P., Rodgers, K., and Levin, I.: Excess radiocarbon constraints on air-sea gas exchange and the uptake of $\mathrm{CO}_{2}$ by the oceans, Geophys. Res. Lett., 33, L11802, doi:10.1029/2005GL025408, 2006.

NCL Version 6.2.0, Boulder, C. U.: The NCAR Command Language, doi:10.5065/D6WD3XH5, 2014.

O'Leary, M. H.: Measurement of the isotope fractlonation associated with diffusion of carbon dioxide in aqueous solution, $\mathrm{J}$. Phys. Chem., 88, 823-825, 1984.

Orr, J. C.: Global Ocean Storage of Anthropogenic Carbon (GOSAC), Tech. rep., EC Environment and Climate Program, Final Report, 2002.

Orr, J., Najjar, R., Sabine, C., and Joos, F.: AbioticHOWTO, Technical report, revision: 1.16, available at: http://ocmip5.ipsl.jussieu.fr/OCMIP/phase2/simulations/

Abiotic/HOWTO-Abiotic.html (last access: 15 May 2012), 2000.

Peacock, S.: Debate over the ocean bomb radiocarbon sink: closing the gap, Global Biogeochem. Cy., 18, GB2022, doi:10.1029/2003GB002211, 2004.

Petit, J. R., Jouzel, J., Raynaud, D., Barkov, N. I., Barnola, J.-M., Basile, I., Bender, M., Chappellaz, J., Davis, M., G, D., Delmotte, M., Kotlyakov, V. M., Legrand, M., Lipenkov, V. Y., Lorius, C., Pepin, L., Ritz, C., Saltzman, E., and Stievenard, M.: Climate and atmospheric history of the past 420,000 years from the Vostok ice core, Antarctica, Nature, 399, 429-436, 1999.

Polka, J. S., van Beynenb, P., Asmeromc, Y., and Polyakc, V. J.: Reconstructing past climates using carbon isotopes from fulvic acids in cave sediments, Chem. Geol., 360-361, 1-9, doi:10.1016/j.chemgeo.2013.09.022, 2013.

Popp, B. N., Laws, E. A., Ridigare, R. R., Dore, J. E., Hanson, K. L., and Wakeham, S. G.: Effect of phytoplankton cell geometry on carbon isotope fractionation, Geochim. Cosmochim. Ac., 62, 6977, 1998.

Quay, P. D., Tilbrook, B., and Wong, C. S.: Oceanic uptake of fossil fuel $\mathrm{CO}_{2}$ : carbon-13 evidence, Science, 256, 74-79, 1992.

Rau, G. H., Takahashi, T., and Marais, D. J. D.: Latitudinal variations in plankton $\delta^{13} \mathrm{C}$ : implications for $\mathrm{CO}_{2}$ and productivity in past oceans, Nature, 341, 516-518, 1989.

Schmittner, A., Gruber, N., Mix, A. C., Key, R. M., Tagliabue, A., and Westberry, T. K.: Biology and air-sea gas exchange controls on the distribution of carbon isotope ratios $\left(\delta^{13} \mathrm{C}\right)$ in the ocean, Biogeosciences, 10, 5793-5816, doi:10.5194/bg-10-5793-2013, 2013.

Shields, C. A., Bailey, D. A., Danabasoglu, G., Jochum, M., Kiehl, J. T., Levis, S., and Park, S.: The low-resolution CCSM4, J. Climate, 25, 3993-4014, doi:10.1175/JCLI-D-11-00260.1, 2012.
Sikes, C. S., Roer, R. D., and Wilbur, K. M.: Photosynthesis and coccolith formation: inorganic carbon sources and net inorganic reaction of deposition, Limnol. Oceanogr., 25, 248-261, 1980.

Sonnerup, R. E., Quay, P. D., McNichol, A. P., Bullister, J. L., Westby, T. A., and Anderson, H. L.: Reconstructing the ocean ${ }^{13} \mathrm{C}$ Suess effect, Global Biogeochem. Cy., 13, 857-872, doi:10.1029/1999GB900027, 1999.

Stuiver, M. and Polach, H. A.: Discussion: reporting of ${ }^{14} \mathrm{C}$ Data, Radiocarbon, 19, 355-363, 1977.

Sweeney, C., Gloor, E., Jacobson, A. R., Key, R. M., McKinley, G., Sarmiento, J. L., and Wanninkhof, R.: Constraining global air-sea gas exchange for $\mathrm{CO}_{2}$ with recent bomb ${ }^{14} \mathrm{C}$ measurements, Global Biogeochem. Cy., 21, GB2015, doi:10.1029/2006GB002784, 2007.

Tagliabue, A. and Bopp, L.: Towards understanding global variability in ocean carbon-13, Global Biogeochem. Cy., 22, GB1025, doi:10.1029/2007GB003037, 2008.

Toggweiler, J. R., Dixon, K., and Bryan, K.: Simulations of radiocarbon in a coarse-resolution world ocean model 1. Steady state prebomb distributions, J. Geophys. Res., 94, 8217-8242 doi:10.1029/JC094iC06p08217, 1989.

Tortell, P. D., Reinfelder, J. R., and More, F. M. M.: Active uptake of bicarbonate by diatoms, Nature, 390, 243-244, 1997.

Turner, J. V.: Kinetic fractionation of ${ }^{13} \mathrm{C}$ during calcium carbonate precipitation, Geochim. Cosmochim. Ac., 46, 1183-1191, doi:10.1016/0016-7037(82)90004-7, 1982.

Wanninkhof, R.: Relationship between wind speed and gas exchange over the ocean, J. Geophys. Res., 97, 7373-7382, 1992.

Waugh, D. W., Hall, T. M., and Haine, T. W. N.: Relationships among tracer ages, J. Geophys. Res., 108, 3138, doi:10.1029/2002JC001325, 2003.

Yellowstone: Computational and Information Systems Laboratory, National Center for Atmospheric Research, Boulder, CO, Yellowstone: IBM iDataPlex System (Climate Simulation Laboratory), available at: http://n2t.net/ark:/85065/d7wd3xhc (last access: 15 September 2014), 2012.

Zeebe, R. E. and Wolf-Gladrow, D.: $\mathrm{CO}_{2}$ in Seawater: Equilibrium, Kinetic, Isotopes, 3rd Edn., Elsevier Oceanography Series 65, Elsevier Ltd, 2001.

Zhang, J., Quay, P. D., and Wilbur, D. O.: Carbon isotope fractionation during gas-water exchange and dissolution of $\mathrm{CO}_{2}$, Geochim. Cosmochim. Ac., 59, 107-114, 1995.

Ziveri, P., Stoll, H. M., Probert, I., Klaas, C., Geisen, M., J. J. Y., and Ganssen, G.: Stable isotope vital effects in coccolith calcite, Earth Planet. Sc. Lett., 210, 137-149, 2003. 